\title{
Review
}

\section{Advances in Kombucha Tea Fermentation: A Review}

\author{
Laura M. Nyhan ${ }^{1}{ }^{\mathbb{D}}$, Kieran M. Lynch ${ }^{1}$, Aylin W. Sahin ${ }^{1}\left(\mathbb{D}\right.$ and Elke K. Arendt ${ }^{1,2, *}$
}

1 School of Food and Nutritional Sciences, University College Cork, T12 YN60 Cork, Ireland; lnyhan@ucc.ie (L.M.N.); lynch.kieran87@gmail.com (K.M.L.); aylin.sahin@ucc.ie (A.W.S.)

2 APC Microbiome Ireland, University College Cork, Western Road, T12 K8AF Cork, Ireland

* Correspondence: e.arendt@ucc.ie; Tel.: +353-21-4902064; Fax: +353-21-4270213

Citation: Nyhan, L.M.; Lynch, K.M.; Sahin, A.W.; Arendt, E.K. Advances in Kombucha Tea Fermentation: A Review. Appl. Microbiol. 2022, 2 , 73-103. https://doi.org/10.3390/ applmicrobiol2010005

Academic Editor: Fani Mantzouridou

Received: 21 December 2021

Accepted: 14 January 2022

Published: 15 January 2022

Publisher's Note: MDPI stays neutral with regard to jurisdictional claims in published maps and institutional affiliations.

Copyright: (C) 2022 by the authors. Licensee MDPI, Basel, Switzerland. This article is an open access article distributed under the terms and conditions of the Creative Commons Attribution (CC BY) license (https:// creativecommons.org/licenses/by/ $4.0 /)$.

\begin{abstract}
Kombucha is a carbonated, slightly acidic beverage traditionally produced by the fermentation of sweetened tea by a symbiotic culture of bacteria and yeast (SCOBY). The microbial community of kombucha is a complex one, whose dynamics are still not fully understood; however, the emergence of culture-independent techniques has allowed a more comprehensive insight into kombucha microbiota. In recent times, advancements have been made towards the optimisation of the fermentation process, including the use of alternative substrates, defined starter cultures and the modification of fermentation parameters, with the aim of producing an innovative beverage that is improved in terms of its physiochemical, sensory and bioactive properties. The global kombucha market is rapidly increasing, with the rising popularity of the tea attributed in part to its purported health benefits, despite the lack of research in human subjects to substantiate such claims. Accordingly, the incidence of kombucha home-brewing has increased, meaning there is a requirement for individuals to recognise the potential hazards associated with fermentation and the relevant preventative measures to be undertaken to ensure the safe preparation of kombucha. The aim of this review is to provide an update regarding the current knowledge of kombucha production, microbiology, safety and marketing.
\end{abstract}

Keywords: kombucha; tea; beverage; fermentation; bacteria; yeast

\section{Introduction}

Kombucha tea is a non-alcoholic, naturally carbonated beverage prepared by fermenting a solution of sweetened tea with a kombucha culture containing bacteria and yeast. It is believed to have originated in northeast China over 2000 years ago, with the consumption of kombucha first recorded in $220 \mathrm{BC}$ in Manchuria [1]. Following this, it is reported to have travelled to Russia and Eastern Europe in the 1800s and beyond this to Western Europe and North Africa during World War II [2]. Kombucha is known by several names including haipao, teakwass, tea fungus, Manchurian mushroom and kambotscha [3].

Kombucha is produced by fermenting sweetened tea using a symbiotic culture of bacteria and yeast (SCOBY), also known as a pellicle. Acetic acid bacteria (AAB) of the genera Komagataeibacter, Acetobacter and Gluconobacter and yeasts such as Zygosaccharomyces spp., Saccharomyces spp. and Brettanomyces spp. are the core drivers of kombucha fermentation [4,5], although lactic acid bacteria (LAB) such as Lactobacillus and Leuconostoc have also been systematically isolated from the beverage [6,7]. Traditionally, culture-based methods were relied upon for characterisation of the microbial composition of kombucha $[4,8]$, however the emergence of culture-independent techniques such as metabarcoding has allowed for a more in-depth analysis of kombucha microflora and their metabolic activities and interactions [6]. During fermentation, yeasts hydrolyse sucrose to glucose and fructose as a by-product of ethanol fermentation, while $\mathrm{AAB}$ then convert ethanol and glucose into acetic acid and gluconic acid, respectively [9]. Other metabolites formed as a result of kombucha fermentation include lactic, citric, malic and glucuronic acids; vitamins; minerals; and phenolic compounds $[10,11]$. Black or green tea and sucrose are the traditional substrates 
for kombucha fermentation; however, in recent years there has been a shift towards the use of alternative carbon and nitrogen sources, with the aim of increasing the functionality of the final beverage.

The global kombucha market has seen significant growth in recent years, standing at USD 1.84 billion in 2019, with a projected growth rate of $23.2 \%$ by 2027 [12]. The rise in popularity of kombucha is in part attributed to its purported health benefits, having been cited as having such abilities as boosting the immune system, alleviating IBS symptoms, aiding in weight loss and reducing blood pressure, to name but a few. However, most of these claims are unsubstantiated and lack scientific evidence, with few clinical trials carried out to date [13]. Moreover, there have even been reports of toxicity associated with over-consumption of kombucha, particularly in immunocompromised individuals [14-16]. The rising popularity of kombucha as a 'healthy' product has resulted in an increased incidence of home-brewing of the beverage, often using a SCOBY obtained from another household as a starter [17]. Thus, it is imperative that individuals are aware of the potential hazards associated with domestic kombucha production and the preventative measures that should be taken for safe kombucha fermentation [18].

The objective of this review is to provide an update on the current knowledge and research in the area of kombucha. The traditional production and fermentation processes of kombucha will be discussed, along with advancements in the area, such as the use of alternative substrates and adjustment of fermentation parameters. An overview of the microbial composition will be given, with a focus on the emergence of culture-independent methods for microbial characterisation. The safety of kombucha production and associated risks will be outlined, in addition to the purported health benefits and recent progress in the area of human clinical trials. Finally, an overview of the kombucha market will be provided, alongside an analysis of some of the commercial kombucha products.

\section{Kombucha Tea Production}

The typical process of kombucha preparation and fermentation is outlined in Figure 1. Under aerobic conditions, kombucha symbiosis can convert sweetened tea into a slightly carbonated, mildly sour and refreshing beverage. The fermentation process essentially exploits the symbiotic relationship between bacteria and yeast. Sucrose is hydrolysed into glucose and fructose by the yeast, resulting in the production of carbon dioxide and ethanol; in turn, LAB utilise glucose and fructose molecules to produce lactic acid, while AAB utilise glucose and ethanol to produce gluconic acid and acetic acid, respectively. Typically, kombucha is prepared by fermenting sweetened black or green with previously fermented liquid tea broth $(10-20 \% v / v)$ or a tea fungus pellicle. The substrate is incubated statically under aerobic conditions for $7-14$ days at $20^{\circ} \mathrm{C}-30{ }^{\circ} \mathrm{C}$ [9].

Sucrose is by far the most common carbon source used in kombucha fermentation, both because of its ability to provide glucose and fructose for microbial metabolic pathways and its low cost and convenient availability. There is a general consensus that the optimal sucrose concentration lies between $5-10 \% w / v[19,20]$, a range within which the majority of kombucha fermentations are performed. The use of tea in kombucha fermentation is primarily cited as providing a source of nitrogen and minerals for kombucha microorganisms, with dried tea leaves containing $21-28 \%$ protein and amino acids contributing about $6 \% w / w$ of the extract solids. Additionally, the reported levels of glycine, valine, lysine, leucine, alanine, methionine and threonine in tea protein exceed even those of soy proteins (g/100 g protein) [21,22]. Black and green teas sourced from leaves of Camellia sinensis (L.) are traditionally used for kombucha fermentation. For home fermentations, the process is considered complete once the desired level of sourness is achieved, while for experimental or industrial investigations, the fermentation endpoint may be determined by measurement of the $\mathrm{pH}$, total titratable acidity (TTA), alcohol content and sugar concentration. It is generally accepted that $\mathrm{pH}$ of an optimally fermented kombucha (in terms of flavour) should fall between $\mathrm{pH} 2.5$ and $3.5[9,23]$ while a TTA of $\sim 4 \mathrm{~g} / \mathrm{L}$ produces a traditional kombucha beverage of high sensory value $[2,24]$. 


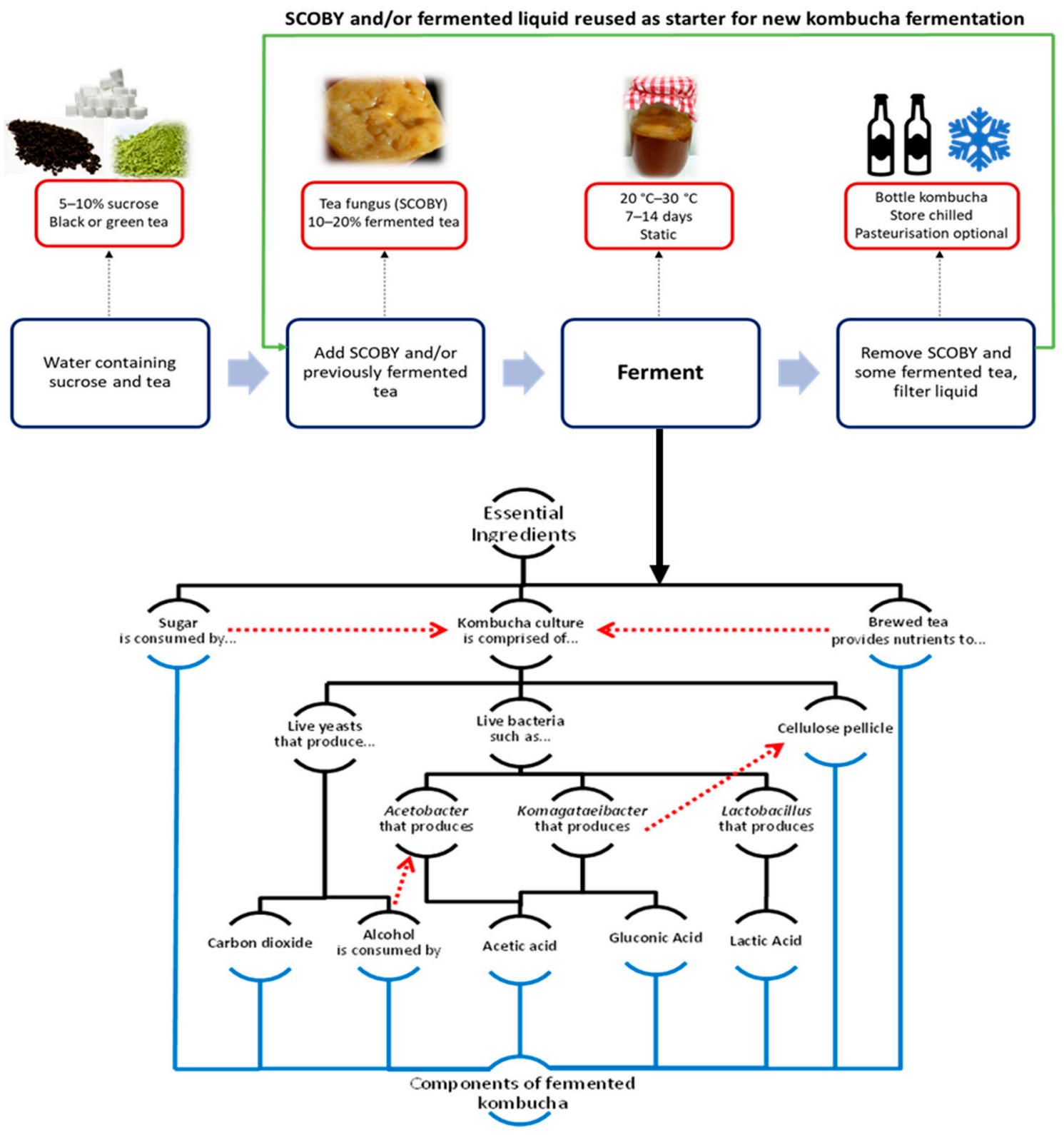

Figure 1. An overview of kombucha preparation and fermentation.

\subsection{Alternative Substrates}

Although sucrose is the most commonly used carbon source in kombucha fermentation, the influence of alternative carbohydrate sources and their respective concentrations on the fermentation process has been investigated (Figure 2). Early studies by Reiss [24] investigated the fermentation characteristics of kombucha teas containing sucrose, glucose, lactose or fructose, with the results showing that the sugar type used distinctly affected the ethanol and lactic acid formation; however, the concentration of the sugars did not have a significant impact. Malbasa et al. [25] found that kombucha produced using molasses as a substrate had higher total acidity, higher lactic acid content and a significantly larger yield of biomass than the sucrose-sweetened kombucha tea, attributed to the greater availability of nitrogen present in the molasses. However, the sensory properties of the obtained kombucha beverage were not satisfactory, with a sweet, caramelised taste and dark colour. Recently, another study investigated molasses as an alternative substrate to sucrose, along with coconut palm sugar. Similar to previous observations [25], kombucha produced with molasses had a higher total acidity level than that of the sucrose-containing kombucha, while notably kombucha tea fermented with coconut palm sugar demonstrated the highest 
antioxidant activity and phenolic content, highlighting its potential for use as a functional beverage [26]. The roles of complex carbohydrate sources in kombucha fermentation have also been studied, with the authors investigating the influence of sucrose substitutes such as Jerusalem artichoke, malt extract and jaggery [27-30]. Of note is a recent study where germinated corn was used as a substrate to produce a no-added-sugar kombucha beverage, the first investigation of kombucha fermentation of exclusively raw seeds or grains with no additional carbon or nitrogen sources. The authors proposed that grains could provide the nutritional requirements for a 'healthy SCOBY', while the soluble fibre could be a suitable substitute for tea alkaloids. The final $\mathrm{pH}$ value of the beverage was similar to that of a commercial kombucha product, while $57.6 \%$ of consumers preferred the germinated corn kombucha over the commercial beverage [31].

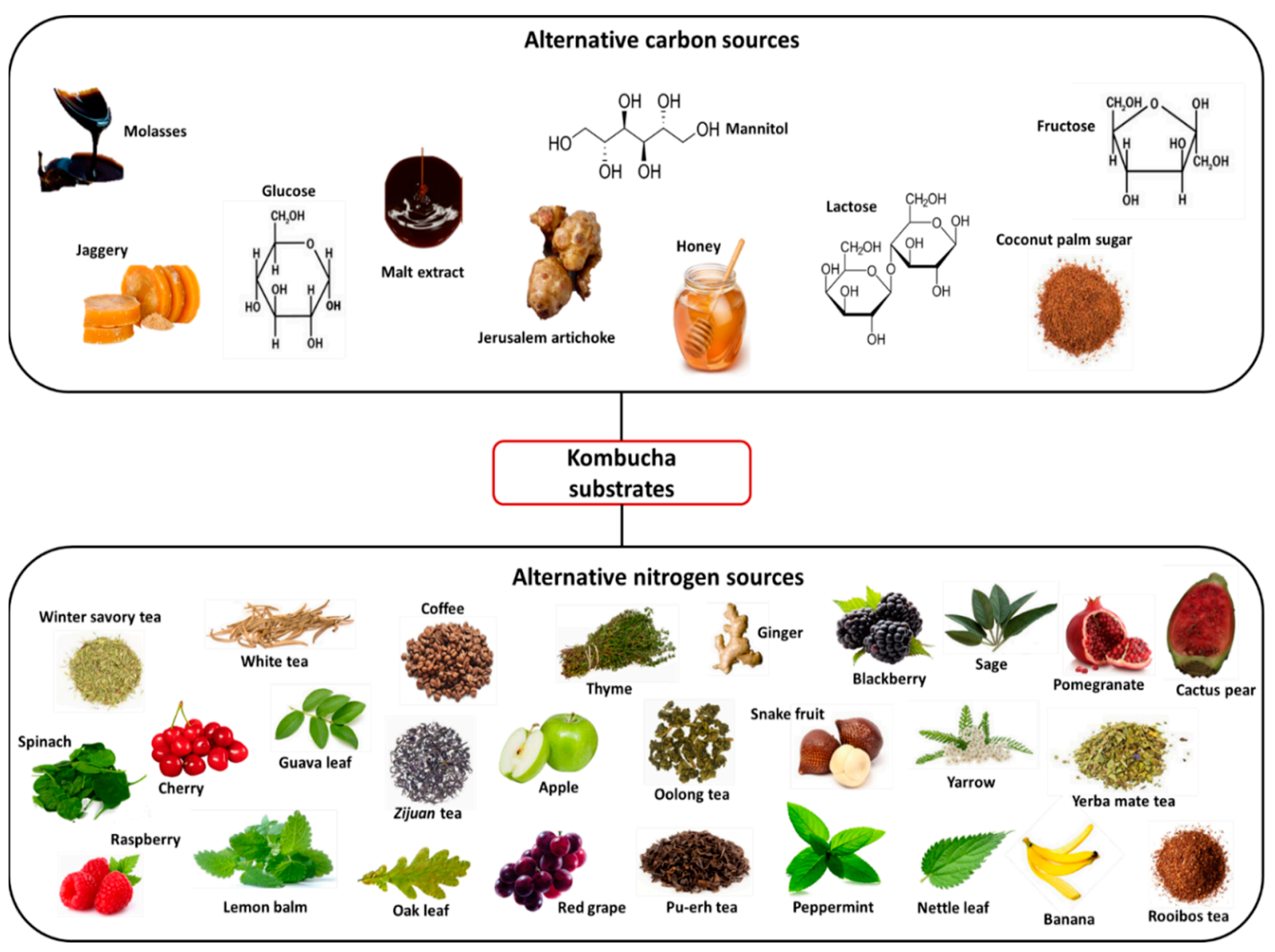

Figure 2. Examples of alternative carbon and nitrogen sources used in kombucha fermentation.

Despite black and green tea being well documented in terms of their functional compounds, such as their flavonoids, polyphenols and saponins, in recent times attention has turned towards the use of alternative tea or nitrogen sources (Figure 2), with the aim of producing a beverage rich in bioactive compounds. Along with black and green tea, the processing of Camellia sinensis (L.) leaves also produces white (non-oxidised), oolong (semi-oxidised) and pu-erh (post-oxidised) teas. A comparative analysis of the influence of each of these tea types on kombucha fermentation revealed that both oolong tea kombucha (OTK) and white tea kombucha (WTK) showed the highest antioxidant capacities during the fermentation, while OTK, WTK and pu-erh tea kombucha (PTK) all had higher bioaccessability values than green or black tea kombucha. Differences between teas were attributed to factors such as the tea leaf processing method, maturation period and relative abundance of phenolic compounds [32]. The functional properties of oolong tea were also highlighted by Tanticharakunsiri et al. [33], resulting in increases in the total 
phenolic content (TPC) and total flavonoid content (TFC) of the kombucha beverage by $6.6 \%$ and $32.26 \%$, respectively, compared to $3.4 \%$ and $12.48 \%$ with mint tea. Teas such as yerba mate, rooibos and Zijuan have also recently been investigated as alternative kombucha substrates, with studies highlighting their superiority compared to black tea kombucha in terms of their increased antioxidant activity, reduced oxidative stress and improved sensory characteristics [34-36]. Interest in the use of herbal teas and medicinal plants as kombucha substrates has also increased, with several studies attempting to harness their associated health benefits and functional properties. Early attempts to use these as kombucha tea alternatives proved unsuccessful, with herbal teas such as peppermint, lime blossom, mint, camomile, rosemary and sage deemed as unsuitable substrates due to the negative effects of their volatile oils, including their poor acidification, interference with the growth of kombucha microbes due to the presence of antimicrobial compounds and storage instability of the beverage [37]. However, Velićanskí et al. [38] found that kombucha could be suitably produced using peppermint or thyme teas, resulting in comparable or shorter fermentation lengths [38], while Tanticharakunsiri et al. [33] and Zhang et al. [39] successfully obtained sensorially acceptable kombucha beverages using mint tea as a substrate. The first use of yarrow (a plant containing over 100 bioactive compounds) as a kombucha substrate was reported by Vitas et al. [40], with the authors exploiting the medicinal properties of the plant to produce a beverage that was characterised as having antimicrobial, anticancer, and antioxidant potential. Other such herbs and plants tested as kombucha substrates include ginger, lemon balm, oak and nettle leaf [38,41-46]. Fruits and vegetables have also emerged as potential kombucha substrates, with researchers again focusing on those wellcharacterised in terms of their bioactive compounds and potential health benefits. Such studies have investigated the use of raw materials such as spinach, grape juice, cherry juice, banana peel and pomegranate juice [45,47-52]. Not only are these substrates beneficial in terms of their functional compounds, but they can also stimulate the increased formation of organic acids such as glucuronic acid under favourable fermentation conditions [50-52].

\subsection{Adjustment of Fermentation Conditions}

Typically, kombucha fermentations are performed for approximately 7-14 days, although this varies greatly in the literature, with reports of fermentations being carried out for up to 60 days [27]. The effects of the fermentation time on the final kombucha beverage have been well-studied, with the results highlighting its significant impacts on the product's bioactive, sensory and microbial characteristics. Vohra et al. [27] reported an increase in antioxidant activity of the kombucha beverage during the first seven days of fermentation, which was attributed to the biotransformation of phytochemicals into polyphenols by enzymes secreted by the kombucha culture. However, a decreasing trend was observed over the remaining 53 days of fermentation. A similar scenario was observed by Zofia et al. [53], whereby the antioxidant effect of kombucha was highest at day 14 of fermentation but was significantly lower on day 28. Additionally, the 14-day-fermented kombucha proved to be less cytotoxic to skin cells than the 28-day-fermented beverage, with the authors speculating that prolonged fermentation may result in the accumulation of harmful levels of organic acids and other metabolites. Based on similar observations, Muhialdin et al. [26] recommended a fermentation period of 12 days for optimal antioxidant activity and phenolic content. The microbial composition of kombucha can also be influenced by fermentation, with an in-depth study by Chakravorty et al. [7] revealing significant changes in microbial community and diversity over 21 days. Candida initially dominated yeast in the liquid portion of the kombucha; however, a shift in dominance to Lachancea spp. on day 7 of the fermentation was observed. In addition, bacterial diversity was higher in the kombucha liquid than in the pellicle, peaking on the seventh day and subsequently decreasing. Interestingly, a similar situation was observed with the biochemical properties of the kombucha, with the radical scavenging ability, reducing power and polyphenol content reaching maximum levels at day 7 , indicating a link between the microbial composition and biochemical activity. Finally, the effect of fermentation time 
on the sensory characteristics of the final beverage must also be considered. In general, a fermentation period of 6-7 days appears to result in a sensorially acceptable beverage, while increasing this often results in a vinegar-like sour flavour $[24,34,43,47,48,54]$.

The fermentation temperatures vary greatly amongst the literature; however, the majority of kombucha fermentations are performed in the range of $20-30{ }^{\circ} \mathrm{C}$. As the optimum growth temperatures of yeast and bacteria differ, it is not surprising that the temperature profile can greatly influence the biochemical reactions taking place during fermentation, with studies showing that the temperature is more impactful on fermentation kinetics than the inoculum concentration [55-57]. Additionally, the metabolic activity of the yeast is critical to provide substrates for $\mathrm{LAB}$ and $\mathrm{AAB}$ in the kombucha culture; thus, fermentations must be performed at a temperature suited to yeast growth [58]. De Filippis et al. [59] investigated the microbial compositions of kombuchas fermented at $20^{\circ} \mathrm{C}$ and $30{ }^{\circ} \mathrm{C}$. The results showed that there was a higher level of diversity in the pellicle at $30{ }^{\circ} \mathrm{C}$, while this temperature also promoted the growth of several LAB and AAB species. Significant differences in microbiota composition of the kombucha beverages were reported. Interestingly, the prevalence of two different species of Gluconacetobacter (Komagataeibacter) was strongly dependent on the fermentation temperature, with G. xylinus (K. xylinus) and G. saccharivorans (K. saccharivorans) dominating at $20^{\circ} \mathrm{C}$ and $30^{\circ} \mathrm{C}$, respectively. Additionally, the increased levels of gluconic and glucuronic acids at $30^{\circ} \mathrm{C}$ positively correlated with the presence of $G$. saccharivorans. Antioxidant activity during fermentation is another factor that is primarily affected by temperature, with Hur et al. [60] commenting that as temperature increases, so too does the polyphenol content, up until a point where too high of a temperature will result in polyphenol oxidation.. The optimal fermentation temperature will also be determined by the kombucha substrate, as evidenced by Vitas et al. [57], whereby the sensory acceptability of kombucha produced using stinging nettle or winter savoury plant was highly dependent on the herbal tea used, with the kombucha beverages scoring highest when produced at $43^{\circ} \mathrm{C}$ or $40^{\circ} \mathrm{C}$, respectively.

\section{Microbial Diversity}

Kombucha fermentation consists of metabolically active bacteria and yeast, which thrive in two mutually non-exclusive compartments: the fermented liquid and the pellicle or biofilm floating on it [7]. The microbial composition of kombucha varies greatly from one batch to another and is dependent on the origin, substrate and fermentation conditions (Table 1). Whilst no yeast has been found to be universally associated with kombucha fermentation, species from genera such as Zygosaccharomyces, Saccharomyces, Brettanomyces, Pichia and Candida are amongst the most common isolates [4,8,61-63]. AAB appear to dominate the microbial community, with the main isolated species affiliated with the Komagataeibacter, Acetobacter and Gluconobacter genera. Komagataeibacter xylinus (formerly Gluconacetobacter xylinus) is thought to be one of the most important species associated with kombucha fermentation, due to its superior cellulose-synthesising ability [64-66]. LAB are not consistently present; however, the systematic isolation of species from genera such as Lactobacillus, Leuconostoc and Bifidobacterium has been reported $[35,67,68]$.

Notwithstanding the widespread applicability and popularity of culture-based techniques, studies reliant on such methods are limited in that only minor parts of complex microbial communities are generally culturable, while less-abundant microbes are often overshadowed by dominating ones [7]. Moreover, the potential for high-throughput analysis is severely reduced, with only a finite number of isolates ever being investigated [6]. The emergence of culture-independent techniques has allowed for a deeper insight into the complex microbial population of kombucha and the metabolic interactions occurring within $[6,7,67]$. Marsh et al. [6] were the first to perform a high-throughput sequence-based analysis of the fungal and bacterial populations of five kombucha pellicles and the resultant fermented tea. Contrary to previous studies $[4,8,62]$, reads assigned to Gluconacetobacter $(>85 \%)$ greatly exceeded those of Acetobacter $(<2 \%)$, which may partially have been due to the reclassification of Acetobacter xylinum to Ga. xylinus (now known as K. xylinus) previ- 
ously. The authors also noted the possibility that reads assigned to Gluconacetobacter may belong to the genus Komagataeibacter, as microbial databases had not yet been updated to reflect the reclassification at the time of publication. Interestingly, a considerable abundance of LAB (Lactobacillus, Bifidobacterium, Lactococcus, Leuconostoc) was detected, a novel finding considering Lactobacilli had been isolated from kombucha in just two studies previous to this $[68,69]$, while the presence of Leuconostoc had not previously been reported. Zygosaccharomyces was the dominant yeast in the fermented beverage, while nine yeast species that had not before been associated with kombucha, including L. fermentati, K. marxianus and Wallemia sebi, were also detected. Zygosaccharomyces was also identified as the dominant yeast in a study by Arikan et al. [70], which used a combination of whole-metagenome shotgun (WMS) and amplicon sequencing to characterise the microbial composition of kombucha. Through gene prediction and gene cluster screening, copper-binding peptides were detected, which the authors speculated may be responsible for the copper biosorption characteristics of kombucha and its toxicity when brewed in metal vessels. Lachancea and Kluveromyces were also isolated from kombucha by Chakravorty et al. [7]; however, in contrast to findings by Marsh et al. [6], Zygosaccharomyces was absent, with the yeast community instead being dominated by Candida, the first observation of this phenomenon. In this study, both D1-D2 LSU and ITS2 genes were sequenced, an approach that is thought to better elucidate the dynamics of the yeast community than sequencing of just a single gene. Until addressed by Coton et al. [67], culture-independent techniques had not been utilised to identify kombucha bacterial communities to species-level. Using partial $16 \mathrm{~S}$ rRNA gene sequencing ( $1500 \mathrm{bp}$ ), members of the Acetobacteraceae family (Gluconobacter, Gluconacetobacter, Acetobacter) were identified as the dominant bacterial species, followed by Lactobacteriaceae. Interestingly, the substrate choice impacted the bacterial composition of the fermented tea, with $\mathrm{O}$. oeni and $\mathrm{Lb}$. nagelii being present in both black and green tea kombuchas and an additional species ( $\mathrm{Lb}$. satsumensis) being detected in just the black tea fermentation. Dekkera, Hanseniaspora and Zygosaccharomyces were identified as the dominant yeasts, while the tea type did not appear to influence the yeast community. Conversely, Gaggia et al. [35] found that the tea substrate choice (black, red or rooibos) did indeed affect the fungal diversity but did not impact the bacterial composition, with Komagataeibacter spp. dominating all kombuchas. Notably, the SCOBY archetype has also been shown to influence the microbial composition of kombucha, with Harrison and Curtin [71] observing differences in the diversity of microbiota between the upper and lower layers of the pellicle. The top layer was more enriched in bacterial and fungal cell numbers, with increases of $3 \log \mathrm{CFU} / \mathrm{mL}$ and $2 \log \mathrm{CFU} / \mathrm{mL}$, respectively, compared to the bottom SCOBY layer. As the SCOBY usually floats to the surface of the kombucha during fermentation, parameters such as oxygen and nutrient availability and temperature vary between the upper and lower surfaces, likely influencing the microbial composition. In this study, the dominating microorganisms of the upper SCOBY layer were determined to be Komagataeibacter and Brettanomyces, taxa which both have an affinity for oxygen; in contrast, the abundance of Lactobacillus in the lower pellicle was significantly higher, most likely due to its preference for a high-nutrient, low-oxygen growth environment. The microbiota of the pellicle also appears to be subject to a selection process during the fermentation, with Gaggia et al. [35] reporting that the abundance of yeasts in the fermented tea did not match that of the biofilm. 
Table 1. Studies investigating the microbial composition of kombucha.

\begin{tabular}{|c|c|c|c|c|c|c|c|c|}
\hline Yeast & $\begin{array}{c}\text { Lactic Acid } \\
\text { Bacteria }\end{array}$ & $\begin{array}{c}\text { Acetic Acid } \\
\text { Bacteria }\end{array}$ & Culture & Inoculum Type & $\begin{array}{l}\text { Fermentation } \\
\text { Substrates }\end{array}$ & $\begin{array}{l}\text { Fermentation } \\
\text { Temperature }\end{array}$ & $\begin{array}{c}\text { Fermentation } \\
\text { Time }\end{array}$ & Reference \\
\hline $\begin{array}{c}\text { Brettanomyces, } \\
\text { Zygosaccharomyces, } \\
\text { Saccharomyces, Candida }\end{array}$ & n.d. & n.d. & Dependent & $\begin{array}{l}\text { Pellicle and liquid } \\
\qquad(n=34)\end{array}$ & $\mathrm{n} / \mathrm{a}$ & $\mathrm{n} / \mathrm{a}$ & $\mathrm{n} / \mathrm{a}$ & [5] \\
\hline Zygosaccharomyces sp. & n.d. & $\begin{array}{l}\text { Acetobacter }(A .) \\
\text { xylinum }\end{array}$ & Dependent & $\begin{array}{l}\text { Pellicle (3-4 layers) } \\
\text { and liquid }(10 \% v / v)\end{array}$ & $\begin{array}{c}67.5 \mathrm{~g} / \mathrm{L} \text { sucrose, } \\
1.5 \mathrm{~g} / \mathrm{L} \text { tea }\end{array}$ & $20^{\circ} \mathrm{C}-22{ }^{\circ} \mathrm{C}$ & $60 \mathrm{~d}$ & [8] \\
\hline $\begin{array}{l}\text { Zygosaccharomyces (Z.) bailii, } \\
\text { Saccharomyces (S.) cerevisiae, } \\
\text { Brettanomyces (B.) bruxellensis }\end{array}$ & n.d. & $\begin{array}{l}\text { A. aceti, } A \text {. } \\
\text { pasteurianus }\end{array}$ & Dependent & $\begin{array}{l}\text { Pellicle and liquid } \\
\qquad(n=3)\end{array}$ & $\mathrm{n} / \mathrm{a}$ & $\mathrm{n} / \mathrm{a}$ & $\mathrm{n} / \mathrm{a}$ & [4] \\
\hline $\begin{array}{l}\text { Z. bailii, Schizosaccharomyces } \\
\text { (Sc.) pombe, Torulospora } \\
\text { delbreuckii, Rhodotorula } \\
\text { mucilaginosa, B. bruxellensis, } \\
\text { Candida (C.) stellata }\end{array}$ & n.d. & n.d. & Dependent & $\begin{array}{l}\text { Pellicle and liquid } \\
\qquad(10 \% v / v)\end{array}$ & $\begin{array}{l}100 \mathrm{~g} / \mathrm{L} \text { sucrose, } \\
5.4 \mathrm{~g} / \mathrm{L} \text { black tea }\end{array}$ & $20^{\circ} \mathrm{C}-22{ }^{\circ} \mathrm{C}$ & $14 \mathrm{~d}$ & [63] \\
\hline $\begin{array}{c}\text { Isolate } 5 / 3 \text {, isolate } 7 / 2, \\
\text { isolate } 2 / 1\end{array}$ & n.d. & Isolate 5 , isolate 9 & Dependent & $\begin{array}{c}\text { Defined starter } \\
\text { culture of yeasts and } \\
\text { AAB }\left(1 \times 10^{7}-\right. \\
\left.4 \times 10^{8} \mathrm{CFU} / \mathrm{mL}\right)\end{array}$ & $\begin{array}{l}70 \mathrm{~g} / \mathrm{L} \text { sucrose, } \\
7.5 \mathrm{~g} / \mathrm{L} \text { winter } \\
\text { savory tea }\end{array}$ & $28^{\circ} \mathrm{C}$ & $11 \mathrm{~d}$ & [61] \\
\hline S. cerevisiae & $\begin{array}{l}\text { Lactobacillus }(\text { Lb. }) \\
\text { plantarum }\end{array}$ & Gluconacetobacter sp. & Dependent & $\begin{array}{c}\text { Defined starter } \\
\text { culture of yeasts, } \\
\text { LAB and AAB }(1: 1: 1)\end{array}$ & $\begin{array}{c}5 \% \text { sucrose, } \\
7.5 \mathrm{~g} / \mathrm{L} \text { black tea, } \\
\text { green tea or tea } \\
\text { powder }\end{array}$ & $30^{\circ} \mathrm{C}$ & $90 \mathrm{~h}$ & [72] \\
\hline $\begin{array}{c}\text { Dekkera }(D .) \text { bruxellensis, } D . \\
\text { anomala, Z. bisporus, Z. lentus, } \\
\text { Pichia }(P .) \text { kudriavzevii, } \\
\text { Davidiella tassiana, Wallemia sebi, } \\
\text { Lachancea (L.) fermentati, } \\
\text { Leucosporidiella fragaria, } \\
\text { Kazachstania unispora, } \\
\text { Kluyveromyces marxianus, } \\
\text { Naumovozyma castelli, } \\
\text { Hanseniaspora }(H .) \text { vineae }\end{array}$ & $\begin{array}{l}\text { Lactobacillus, } \\
\text { Lactococcus, } \\
\text { Leuconostoc, } \\
\text { Bifidobacterium }\end{array}$ & $\begin{array}{c}\text { Acetobacter, } \\
\text { Gluconacetobacter }\end{array}$ & Independent & $\begin{array}{c}\text { Pellicle }(10 \% w / v) \\
\text { and liquid }(10 \% v / v)\end{array}$ & $\begin{array}{c}10 \% \text { sucrose } \\
0.49 \% \text { black tea }\end{array}$ & $23^{\circ} \mathrm{C}$ & $10 \mathrm{~d}$ & [6] \\
\hline
\end{tabular}


Table 1. Cont.

\begin{tabular}{|c|c|c|c|c|c|c|c|c|}
\hline Yeast & $\begin{array}{l}\text { Lactic Acid } \\
\text { Bacteria }\end{array}$ & $\begin{array}{l}\text { Acetic Acid } \\
\text { Bacteria }\end{array}$ & Culture & Inoculum Type & $\begin{array}{l}\text { Fermentation } \\
\text { Substrates }\end{array}$ & $\begin{array}{l}\text { Fermentation } \\
\text { Temperature }\end{array}$ & $\begin{array}{c}\text { Fermentation } \\
\text { Time }\end{array}$ & Reference \\
\hline $\begin{array}{c}\text { Candida, Lachancea, } \\
\text { Kluyveromyces, Debaryomyces, } \\
\text { Pichia, Waitea, Eromothecium, } \\
\text { Meyerozyma,Zygowilliopsis, } \\
\text { Saccharomyces, } \\
\text { Saccharomycopsis, Hanseniaspora, } \\
\text { Kazachstania, Starmera, } \\
\text { Merimbla, Sporopachydermia, } \\
\text { Sugiyamaella }\end{array}$ & $\begin{array}{l}\text { Lactobacillus, } \\
\text { Weissella, } \\
\text { Bifidobacterium }\end{array}$ & $\begin{array}{l}\text { Komagataeibacter, } \\
\text { Gluconobacter }\end{array}$ & Independent & $\begin{array}{l}\text { Pellicle and liquid } \\
\qquad(10 \% v / v)\end{array}$ & $\begin{array}{l}10 \% \text { sucrose, } 5 \\
\mathrm{~g} / \mathrm{L} \text { black tea }\end{array}$ & $28^{\circ} \mathrm{C}$ & $21 \mathrm{~d}$ & [7] \\
\hline Z. bailii & n.d. & $\begin{array}{l}\text { Komagataeibacter } \\
\text { (K.) saccharivorans }\end{array}$ & Dependent & $\begin{array}{c}\text { Pellicle }(3 \% w / v) \\
\text { and liquid }(10 \% v / v)\end{array}$ & $\begin{array}{l}10 \% \text { sucrose } \\
2 \% \text { tea }\end{array}$ & Room temp & $28 \mathrm{~d}$ & [73] \\
\hline $\begin{array}{l}\text { C. boidinii, } D \text {. anomala, } D \text {. } \\
\text { bruxellensis, } H \text {. valbyensis, } \\
\text { Wickerhamomyces anomalus, } P \text {. } \\
\text { membranifaciens, S. cerevisiae, S. } \\
\text { uvarum, Torulaspora } \\
\text { microellipsoides, Z. bailii, Z. } \\
\text { florentina }\end{array}$ & $\begin{array}{l}\text { Oenococcus (O.) } \\
\text { oeni, Lb. nagelii, L. } \\
\text { satsumensis }\end{array}$ & $\begin{array}{l}\text { A. lovaniensis, } A \text {. } \\
\text { okinawensis, } A \text {. } \\
\text { peroxydans, } A \\
\text { syzgii, } A \text {. } \\
\text { tropicalis, } \\
\text { Gluconacetobacter } \\
\text { (Ga.) eurapaeus, } \\
\text { Ga. hansenii, } G a \text {. } \\
\text { intermedius, Ga. } \\
\text { liquefaciens, Ga. } \\
\text { xylinus, } \\
\text { Gluconobacter (G.) } \\
\text { cerinus, } G \text {. } \\
\text { oxydans, } \\
\text { Tanticharoemia } \\
\text { sakaeratensis }\end{array}$ & $\begin{array}{l}\text { Dependent } \\
\text { and } \\
\text { independent }\end{array}$ & $\mathrm{n} / \mathrm{a}$ & $\begin{array}{l}\text { Sweetened black } \\
\text { and green tea }\end{array}$ & $\mathrm{n} / \mathrm{a}$ & $8 \mathrm{~d}$ & [67] \\
\hline $\begin{array}{c}\text { Dekkera, Pichia, } \\
\text { Zygosaccharomyces }\end{array}$ & $\begin{array}{l}\text { Lactobacillus, } \\
\text { Leuconostoc, } \\
\text { Lactococcus, } \\
\text { Bifidobacterium }\end{array}$ & $\begin{array}{l}\text { Gluconacetobacter, } \\
\text { Acetobacter }\end{array}$ & Independent & Pellicle $(3 \% w / v)$ & $\begin{array}{l}\text { 10\% sugar source } \\
\text { (Aspartame, bees' } \\
\text { honey, glucose, } \\
\text { Caryota urens } \\
\text { honey or } \\
\text { Palmyrah } \\
\text { jaggery), } 10 \mathrm{~g} / \mathrm{L} \\
\text { black tea }\end{array}$ & $24^{\circ} \mathrm{C}$ & $7 \mathrm{~d}$ & [74] \\
\hline n.d. & $\begin{array}{l}\text { Lactobacillus, } \\
\text { Lactococcus, } \\
\text { Streptococcus }\end{array}$ & $\begin{array}{l}\text { Acetobacter, Ga. } \\
\text { xylinus, Ga. } \\
\text { saccharivorans }\end{array}$ & $\begin{array}{l}\text { Dependent } \\
\text { and } \\
\text { independent }\end{array}$ & $\begin{array}{l}\text { Pellicle }(20 \mathrm{~g} / \mathrm{L}) \text { and } \\
\text { liquid }(3 \% v / v)\end{array}$ & $\begin{array}{c}100 \mathrm{~g} / \mathrm{L} \text { sucrose, } \\
10 \mathrm{~g} / \mathrm{L} \text { black or } \\
\text { green tea }\end{array}$ & $20^{\circ} \mathrm{C}$ or $30^{\circ} \mathrm{C}$ & $21 \mathrm{~d}$ & [59] \\
\hline
\end{tabular}


Table 1. Cont.

\begin{tabular}{|c|c|c|c|c|c|c|c|c|}
\hline Yeast & $\begin{array}{c}\text { Lactic Acid } \\
\text { Bacteria }\end{array}$ & $\begin{array}{c}\text { Acetic Acid } \\
\text { Bacteria }\end{array}$ & Culture & Inoculum Type & $\begin{array}{l}\text { Fermentation } \\
\text { Substrates }\end{array}$ & $\begin{array}{l}\text { Fermentation } \\
\text { Temperature }\end{array}$ & $\begin{array}{c}\text { Fermentation } \\
\text { Time }\end{array}$ & Reference \\
\hline B. bruxellensis, Z. parabailii & $\begin{array}{l}\text { Lactobacillaceae, } \\
\text { Leuconostocaceae, } \\
\text { Streptococcaceae }\end{array}$ & $\begin{array}{l}\text { K. intermedius, } K \text {. } \\
\text { rhaeticus, Ga. } \\
\text { entanii }\end{array}$ & $\begin{array}{l}\text { Dependent } \\
\text { and } \\
\text { independent }\end{array}$ & $\begin{array}{c}\text { Pellicle }(3 \% w / v) \\
\text { and liquid }(10 \% v / v)\end{array}$ & $\begin{array}{l}80 \mathrm{~g} / \mathrm{L} \text { sucrose, } \\
8 \mathrm{~g} / \mathrm{L} \text { black, } \\
\text { green or } \\
\text { rooibos tea }\end{array}$ & $27^{\circ} \mathrm{C}$ & $14 \mathrm{~d}$ & [35] \\
\hline B. bruxellensis & n.d. & $\begin{array}{l}\text { Komagataeibacter } \\
\text { sp. DS1MA.62A, } \\
\text { K. xylinus, K. } \\
\text { saccharivorans, Ga. } \\
\text { saccharivorans }\end{array}$ & Dependent & Liquid $(10 \% v / v)$ & $\begin{array}{l}10 \% \text { molasses in } \\
\text { acetate buffer } \\
(200 \mathrm{mM}, \\
\text { pH } 4.75)\end{array}$ & Room temp & $6 \mathrm{~d}$ & [75] \\
\hline Zygosaccharomyces, Z. bailii & n.d. & $\begin{array}{l}\text { Komagataeibacter, } \\
\text { K. rhaeticus }\end{array}$ & Independent & $\begin{array}{l}\text { Pellicle }\left(100 \mathrm{~mm}^{2}\right) \\
\text { and liquid }(10 \% \mathrm{v} / \mathrm{v})\end{array}$ & $\begin{array}{l}10 \mathrm{~g} / \mathrm{L} \text { sucrose } \\
6 \mathrm{~g} / \mathrm{L} \text { tea }\end{array}$ & $28^{\circ} \mathrm{C}$ & $15 \mathrm{~d}$ & {$[70]$} \\
\hline $\begin{array}{l}\text { C. arabinofermentans, } B \text {. } \\
\text { bruxellensis, Sc. pombe, Z. bailii }\end{array}$ & n.d. & $\begin{array}{l}\text { A. maolroum, } A . \\
\text { pasteurianus, } A . \\
\text { pomorum, } A . \\
\text { tropicalis, } K . \\
\text { rhaeticus, } K . \\
\text { xylinus, } K . \\
\text { europaeus, } K . \\
\text { intermedius, G. } \\
\text { oxydans, } \\
\text { Gluconacetobacter } \\
\text { sp. SXCC-1 }\end{array}$ & Independent & $\begin{array}{c}\text { Pellicle }(2 \% w / v) \\
\text { and liquid }(2 \% v / v)\end{array}$ & $\begin{array}{l}70 \mathrm{~g} / \mathrm{L} \text { sucrose, } \\
10 \mathrm{~g} / \mathrm{L} \text { black tea }\end{array}$ & $25^{\circ} \mathrm{C}$ & $14 \mathrm{~d}$ & [76] \\
\hline Z. bailii & n.d. & $\begin{array}{l}\text { A. pasteurianus, } \\
\text { Ga. xylinus }\end{array}$ & Dependent & $\begin{array}{c}\text { Defined starter } \\
\text { culture of } \mathrm{Z} \text {. bailii } \\
\left(10^{5} \mathrm{CFU} / \mathrm{mL}\right), A \\
\text { pasteurianus } \\
\left(10^{5} \mathrm{CFU} / \mathrm{mL}\right) \text { and } \\
\text { Ga. xylinus } \\
\left(10^{6} \mathrm{CFU} / \mathrm{mL}\right)\end{array}$ & $\begin{array}{l}100 \mathrm{~g} / \mathrm{L} \text { sucrose, } \\
8 \mathrm{~g} / \mathrm{L} \text { black tea }\end{array}$ & $29^{\circ} \mathrm{C}$ & $10 \mathrm{~d}$ & [77] \\
\hline $\begin{array}{c}\text { Brettanomyces, } \\
\text { Zygosaccharomyces, Starmerella, } \\
\text { Lachancea, Saccharomycetales, } \\
\text { Candida, Hanseniaspora, Pichia, } \\
\text { Ascomycota, Kregervanrija }\end{array}$ & $\begin{array}{l}\text { Lactobacillus, } \\
\text { Oenococcus }\end{array}$ & $\begin{array}{l}\text { Komagataeibacter, } \\
\text { Acetobacter, } \\
\text { Gluconobacter, } \\
\text { Gluconacetobacter }\end{array}$ & Independent & Pellicle $(n=103)$ & $\mathrm{n} / \mathrm{a}$ & $\mathrm{n} / \mathrm{a}$ & $\mathrm{n} / \mathrm{a}$ & [71] \\
\hline
\end{tabular}


Table 1. Cont.

\begin{tabular}{|c|c|c|c|c|c|c|c|c|}
\hline Yeast & $\begin{array}{c}\text { Lactic Acid } \\
\text { Bacteria }\end{array}$ & $\begin{array}{c}\text { Acetic Acid } \\
\text { Bacteria }\end{array}$ & Culture & Inoculum Type & $\begin{array}{l}\text { Fermentation } \\
\text { Substrates }\end{array}$ & $\begin{array}{l}\text { Fermentation } \\
\text { Temperature }\end{array}$ & $\begin{array}{c}\text { Fermentation } \\
\text { Time }\end{array}$ & Reference \\
\hline B. bruxellensis, Z. bisporus & n.d. & $\begin{array}{l}\text { Acetobacteraceae, } \\
\text { K. rhaeticus, } K . \\
\text { hansenii, } K . \\
\text { xylinus }\end{array}$ & Independent & $\begin{array}{c}\text { Pellicle }(4 \% w / v) \\
\text { and liquid }(10 \% v / v)\end{array}$ & $\begin{array}{l}70 \mathrm{~g} / \mathrm{L} \text { glucose } \\
\text { and fructose } \\
\text { mixture }(1: 1), \\
0.5 \% \text { green tea }\end{array}$ & $30^{\circ} \mathrm{C}$ & $15 \mathrm{~d}$ & [78] \\
\hline $\begin{array}{c}\text { D. bruxellensis, } H . \text { uvarum, } Z \text {. } \\
\text { bailii }\end{array}$ & Lb. nagelii, O. oeni & $\begin{array}{l}\text { A. tropicalis, } A \text {. } \\
\text { okinawensis, } K . \\
\text { hansenii, G. } \\
\text { oxydans }\end{array}$ & Independent & $\begin{array}{c}\text { Defined starter } \\
\text { culture of yeasts, } \\
\text { LAB and AAB } \\
\left(10^{5} \text { CFU / mL of }\right. \\
\text { each })\end{array}$ & $\begin{array}{l}55 \mathrm{~g} / \mathrm{L} \text { blond } \\
\text { sugar, green tea }\end{array}$ & $25^{\circ} \mathrm{C}$ & $27 \mathrm{~d}$ & [79] \\
\hline $\begin{array}{l}\text { B. bruxellensis, } H \text {. valbyensis, } S \text {. } \\
\text { cerevisiae }\end{array}$ & n.d. & $\begin{array}{l}\text { A. papayae, Ga. } \\
\text { takamatsuzukensis }\end{array}$ & Dependent & Liquid $(12 \% v / v)$ & $\begin{array}{c}60 \mathrm{~g} / \mathrm{L} \text { sucrose, } \\
1 \% \text { black tea }\end{array}$ & $26^{\circ} \mathrm{C}$ & $3 d$ & [80] \\
\hline
\end{tabular}

Note: Genus and species designations are shown as published; n.d.: not detected; n/a: information not available. 


\section{Use of Defined Starter Cultures}

The use of defined strain starter cultures for kombucha fermentation is rare and has been the focus of few research articles to date; thus, the transfer of the kombucha pellicle or fermented liquid from one batch to the next remains the primary method of inoculation. Although sufficient for home-brewing, such a method may be problematic for industrialscale production of kombucha due to uncontrolled shifts in microbial composition and biological activities and a lack of reproducibility [77]. Malbaša et al. [62] investigated the use of two different starter cultures for kombucha fermentation; the first a combination of Saccharomyces cerevisiae and mixed AAB (starter culture 1; SC1) and the other a mix of Zygosaccharomyces spp. and AAB (SC2). It was reported that SC1 resulted in a kombucha beverage with significantly higher levels of antioxidant activity than SC2 when black tea was used as a substrate; however, the native kombucha consortium (SCOBY) displayed superior antioxidant activity on green tea. Fu et al. [72] discussed the use of equal amounts $\left(10^{8} \mathrm{CFU} / \mathrm{mL}\right)$ of S. cerevisiae Meyen ex E.C. Hansen, Gluconacetobacter spp. and Lb. plantarum, strains previously reported to be optimal for kombucha fermentation [81]. The kombucha beverage produced using green tea exhibited the highest antioxidant potential, although microbiological analysis of the kombucha stored at $4{ }^{\circ} \mathrm{C}$ for 14 days showed poor survival of $\mathrm{Lb}$. plantarum (0.98\%) compared to that of S. cerevisiae (73.97\%) or Gluconacetobacter spp. (54.09\%). A tailor-made kombucha consortium consisting of two LAB species, four $\mathrm{AAB}$ species and three yeast species previously isolated from kombucha and thought to be the main drivers of the fermentation process was recently designed by Savary et al. [79]. The authors carried out an in-depth analysis of the biochemical, physicochemical and microbial parameters of fermentation and were the first to report on the coupling of fluorescent in situ hybridisation (FISH) probes with confocal laser scanning microscopy (CLSM) and scanning electron microscopy (SEM) to monitor the progressive formation of the kombucha biofilm. The results showed that AAB dominated the biofilm, with evidence to suggest that yeast and bacterial species may also have contributed to its formation, a phenomenon that has previously been described in the literature [82-84]. Interestingly, a correlation between shifts in yeast, $\mathrm{LAB}$ and $\mathrm{AAB}$ dominance and changes in the volatile profile of the kombucha was established. The production of aldehydes during the early stages of fermentation was linked to high abundance levels of H. uvarum, O. oeni and Z. bailii, with ethanol, esters, and diacetyl formation during days 11-14 correlated with high AAB counts in the biofilm. Lastly, a shift in dominance towards D. bruxellensis, A. tropicalis and $L b$. nagelii during the late stage (days 20-27) of the fermentation correlated with increased contents of organic acids, esters, and ketones. A study by Wang et al. [77] compared the biochemical and sensory properties of kombucha prepared using a SCOBY to one prepared using a defined starter culture of AAB (A. pasteurianus and $G a$. xylinus) and yeast (Z. bailii). The use of the starter culture accelerated the fermentation and resulted in a beverage with increased levels of phenolic compounds and comparable sensorial characteristics to those of the traditionally prepared kombucha. Although research in this area is lacking, the use of defined starter cultures is a promising alternative to the traditional kombucha inoculation method, allowing for customisation of the microbial composition and enhancement of the sensory and functional properties of the tea.

\section{Potential Health Benefits}

\subsection{Clinical Trials}

The rising popularity of kombucha is due in part to its purported health benefits, such as the improvement of depression and anxiety, prevention of cancer, reductions in blood pressure and cholesterol, prevention of hair loss, and weight loss; however, many of these claims are based off anecdotal evidence and testimonials and very few can be substantiated with actual scientific evidence. Furthermore, the validation of such claims in human clinical trials is rare, with a systematic literature review performed in 2018 identifying just one uncontrolled empirical human subject study investigating the effects of kombucha consumption on health [13]. During the writing of this review, we performed a similar 
search of clinicaltrials.gov and the EU clinical trials register (www.clinicaltrialsregister.eu) (accessed on 8 December 2021) to establish whether any kombucha-associated human subject studies had been registered since 2018. The search identified three clinical trials investigating the effects of kombucha on human health, one of which is still ongoing (Table 2). Bergström [85] evaluated the effect of daily consumption of either living kombucha (intervention group), heat-sterilised kombucha (placebo group) or tap water (control group) on the gut microbiota, with the results revealing that kombucha consumption had no significant effect on the microbial communities of the participants. Prior to the trial, all participants were required to undertake a 2-week 'washout period', during which they were prohibited from consuming foods with high amounts of living microorganisms, such as probiotic drinks, yoghurts, kombucha or fermented products. These dietary restrictions continued throughout the 3-week trial period and for an additional 10 days post-trial; however, no details were provided regarding the diet of the participants throughout the study. Therefore, differences in the subjects' dietary patterns could have affected the outcome of the trial. The second study investigated the hyperglycaemic therapeutic effect of kombucha consumption on 12 human participants, while the third trial is also focused on the potential impacts of kombucha on blood sugar levels. Unfortunately, data and findings from these trials were not available. Although the increased interest in kombucha research with human subjects is encouraging, the lack of advancements in this area is remarkable considering the significant rise in the commercialisation of kombucha and the widespread belief that the beverage supports health [13]. Consequently, the purported health benefits of kombucha are based solely on in vitro and in vivo studies and looks set to remain this way until significant progress is made in the form of rigorous clinical trials.

\subsection{In Vitro and In Vivo Studies}

The antimicrobial activity of kombucha has mainly been attributed to the high organic acid content and correspondingly low $\mathrm{pH}$ of the beverage [11]. Several studies have reported antimicrobial effects against both Gram-positive and Gram-negative bacteria such as Listeria monocytogenes, Staphylococcus aureus, Bacillus cereus, Escherichia coli and Klebsiella pneumoniae [40,89-92]. Antimicrobial activity is typically determined using endpoint methods such as disc diffusion assays or minimum inhibitory concentration (MIC) assays that have inherent advantages but provide insight as to how a compound impacts bacterial growth over time, particularly in a liquid or food matrix. Al-Mohammadi et al. [93] demonstrated the effect of kombucha tea on pathogen growth in BHI broth and fruit juices, with the results revealing a significant decrease in cell numbers of E. coli and S. aureus in strawberry, apple, guava and tomato juices, and in all cases complete growth inhibition within $96 \mathrm{~h}$ when treated with $2 \%$ or $4 \%$ kombucha tea. The authors also observed that neutralised kombucha also inhibited bacterial growth, suggesting that the antimicrobial activity of the kombucha tea was not solely due to acetic acid content or low $\mathrm{pH}$ but also bioactive compounds such as alkaloids, heterocyclic compounds and esters produced during fermentation. Ayed et al. [48] came to a similar conclusion regarding their investigation of the antimicrobial activity of kombucha tea against a range of bacteria. Kombucha has also been shown to exert antifungal activity against yeasts such as C. albicans, C. krusei, C. galbrata and A. fumigatus $[94,95]$. Moreover, the fermented tea has even been characterised as possessing antiviral potential against foot and mouth disease virus (FMDV) [96]; however, no other studies to date have documented the antiviral effect of kombucha. 
Table 2. Details of controlled human intervention trials examining the effects of kombucha on human health (data correct as of December 2021).

\begin{tabular}{|c|c|c|c|c|c|c|}
\hline Study Title & Study Status & Participants & Study Type & Intervention Treatment & Location & Source \\
\hline $\begin{array}{l}\text { The effect of the fermented tea } \\
\text { beverage kombucha on the } \\
\text { oral and gut microflora }\end{array}$ & Completed (2018) & 42 & $\begin{array}{l}\text { Interventional; } \\
\text { randomised allocation; } \\
\text { double-blind }\end{array}$ & $\begin{array}{l}\text { Participants will be divided into three } \\
\text { groups, in which one is given living } \\
\text { kombucha (intervention), one } \\
\text { heat-sterilised kombucha (placebo) and } \\
\text { one tap water (control). Dosage: one } \\
\text { bottle ( } 330 \mathrm{~mL} \text { ) daily for } 3 \text { weeks }\end{array}$ & Lund University, Sweden & {$[85,86]$} \\
\hline $\begin{array}{c}\text { Evaluating the effects of } \\
\text { kombucha as a } \\
\text { hyperglycaemic therapeutic } \\
\text { agent within diabetic human } \\
\text { subjects (completed) }\end{array}$ & Completed (2020) & 12 & $\begin{array}{l}\text { Interventional; } \\
\text { randomised allocation; } \\
\text { double-blind }\end{array}$ & $\begin{array}{l}\text { Either ginger kombucha (intervention) } \\
\text { or ginger water (placebo) will be given } \\
\text { to subjects for weeks } 1-4 \text { followed by } \\
\text { the reciprocal beverage for weeks } 6-10\end{array}$ & Georgetown University, USA & [87] \\
\hline $\begin{array}{l}\text { The effect of kombucha on } \\
\text { blood sugar levels in humans } \\
\text { (recruiting) }\end{array}$ & Recruiting & 20 (planned) & $\begin{array}{l}\text { Interventional; } \\
\text { randomised allocation; } \\
\text { single-blind (participant) }\end{array}$ & $\begin{array}{l}\text { At first visit, participants will be } \\
\text { divided into four groups, in which one } \\
\text { is given commercial kombucha } \\
\text { (intervention 1), one brewed kombucha } \\
\text { (intervention 2), one tea (control 1) and } \\
\text { one tap water (control 2). At each } \\
\text { subsequent visit, subjects will be } \\
\text { randomly allocated into one of the } \\
\text { remaining groups until they have } \\
\text { completed each intervention treatment } \\
\text { Dosage: } 8 \mathrm{oz}(237 \mathrm{~mL} \text { ) }\end{array}$ & University of Missouri, USA & [88] \\
\hline
\end{tabular}


Kombucha has been reported to have a hepatoprotective effect on non-alcoholic fatty liver disease (NAFLD), a liver disorder defined by abnormal lipid retention in $>5 \%$ of hepatocytes (steatosis), which can progress to cirrhosis or hepatocellular carcinoma if not properly managed [97]. Cardoso et al. [98] reported that kombucha tea promoted the modulation of lipid metabolism in rats fed a high-fat, high-fructose diet; subsequently, a reduction in the severity of steatosis from grade 2 to grade 1 was observed, an outcome the authors attributed to phenolic compounds and organic acids present in the tea. A similar inference was made in another study, whereby it was suggested that kombucha influences lipid metabolism and protects hepatocytes from lipid toxicity in mice with NAFLD, with liver restoration promoted by the reductions in inflammation and fibrosis [99]. Contrary to these findings, Urrutia et al. [100] reported that kombucha did not affect the lipid profiles of mice fed a cafeteria diet (high fat and high sugar); however, consumption of the tea ( $5 \mathrm{~mL} / \mathrm{kg}$ of body weight) did result in increased satiety and subsequent weight loss compared to the control group, which consumed a saline solution.

The anti-diabetic effect of kombucha has also been tested. Zubaidah et al. [101] reported a 31-59\% reduction in fasting plasma glucose levels of diabetic rats to which snake fruit (a fruit of the Salak palm tree) kombucha was administered orally for 28 days. This decrease in blood glucose levels was thought to be due to the protective and repairing effects of antioxidants in kombucha on pancreatic beta cells, and consequently improved insulin secretion. A later study by the same group found that the anti-diabetic activity of snake fruit kombucha was comparable to that of metformin, highlighting the beverage's potential as an alternative hyperglycaemic therapeutic agent [102]. The anti-inflammatory and immunomodulatory properties of kombucha have been associated with phenolic compounds produced during the fermentation process. Experimental autoimmune encephalomyelitis (EAE) is an animal model in which common pathological symptoms of the inflammatory disease multiple sclerosis (MS) are simulated [103]. Haghmorad et al. [104] observed suppression in the incidence and clinical manifestation of the disease following kombucha treatment, attributed to the inhibition of IFN- $\gamma$ and IL-17 inflammatory cytokines. VázquezCabral et al. [44] observed the suppression of pro-inflammatory cytokines TNF-alpha and IL6 release from macrophages following treatment with oak kombucha (kombucha infused with oak leaves), possibly due to the higher catechin and quercetin glucuronide contents in the beverage than in traditional kombucha, highlighting how the fermentation substrate can also influence the functional properties of the tea [44]. Sknepnek et al. [105] produced novel kombucha beverages using Coriolus versicolor and Lentinus edodes mushrooms as substrates in place of tea, reporting for the first time the immunomodulatory effects of crude polysaccharide extracts. The results suggested that the consumption of such polysaccharide fractions may suppress IL-4 and IL-5, key Th2 cytokines involved in the development of asthma and allergic reactions; however, further in vitro and in vivo studies are required to confirm the authors hypotheses.

\section{Safety of Kombucha}

\subsection{Potential Toxicity}

Despite being promoted as 'healthy' and the 'elixir of life', as previously mentioned there is little evidence in the form of human clinical trials to substantiate such claims. Kombucha consumption has been associated with toxic effects in some cases. For example, Gedela et al. [15] described a patient presenting with nausea, jaundice and dark-coloured urine following consumption of significant amounts of kombucha for the month prior to her admission. Upon inspection, she was diagnosed with moderately active hepatitis, most likely due to drug-induced liver injury. Similar cases of hepatoxicity associated with kombucha consumption have also been reported in the literature $[17,106]$. Srinivasan et al. [14] reported possible side effects of kombucha consumption such as nausea, headaches and jaundice in four different patients, while other conditions that may be linked to kombucha consumption include renal failure [16], myositis [107] and pellagra [108]. However, it should be noted that each of these were isolated cases involving single patients, with 
no substantial evidence implicating kombucha as the sole source of illness or infection. For example, the patient who presented with pellagra had also been taking zinc and calcium supplements and Acidophilus tablets and had a history of medical problems, including dermatitis, mononucleosis and malnourishment [107]. In addition, some of the other patients also had a history of medical conditions such as alcoholism [14], diabetes, hypothyroidism [15,17] and HIV [16]; thus, it cannot be ruled out that their illness and symptoms were not the result of pre-existing medical issues. It should also be considered that in most cases the kombucha consumed was home-brewed, which raises questions regarding the safety of the kombucha; it is possible that an improper kombucha preparation process could result in contamination and adverse medical effects. Thus, it is imperative for kombucha producers to recognise and address the potential hazards associated with kombucha fermentation.

\subsection{Risk Analysis of Kombucha Production}

Although mainly used in industrial food settings, a Hazard Analysis and Critical Control Point (HACCP)-based risk analysis can be applied to the domestic production of kombucha (Table 3). As can be seen, most potential hazards linked with kombucha preparation are biological in nature. Despite tea not being commonly associated with foodborne illness, pathogens such as Salmonella spp., Bacillus spp. Escherichia coli and Clostridium perfringens can survive in low-moisture environments and have been detected in dried herbs and spices at the point of retail [109-111]. It has also been shown that black and green tea can have microbial loads of up to $10^{5} \mathrm{CFU} / \mathrm{g}$ and may contain bacterial and fungal species such as Aspergillus, Shigella and Pseudomonas [112,113]. Boiled water should be used for kombucha preparation to ensure any vegetative pathogens in the water, tea and sugar are killed. The sweetened tea mixture should be inoculated immediately once cooled, as the risk of contamination is at its greatest at this point. Home-brewing of kombucha often results in the propagation and sharing of tea fungus between households $[17,114]$, a practice that increases the risk of biological contamination with the growth of moulds such as Aspergillus and Penicillium, with the subsequent release of mycotoxins being of particular concern $[5,11,114]$. To avoid this, a commercial culture should always be used for the first brew and any kombucha that shows signs of mould contamination or fails to reach a $\mathrm{pH}$ of $\leq 4.2$ during fermentation should be discarded immediately (along with the SCOBY). In general, the presence of pathogenic bacteria in kombucha is rare due to its low $\mathrm{pH}$ and the inability of microorganisms to tolerate such an environment. However, the kombucha 'mushroom' (SCOBY) has been implicated in cases of anthrax, with patients applying the tea fungus to body parts as a painkiller; laboratory analysis subsequently showed that although Bacillus anthrax could not be detected due to the high level of bacterial contamination, samples inoculated with species were able to support its growth [115]. Recently, Brewer et al. [116] demonstrated the ability of Shiga toxin-producing E. coli (STEC) and Salmonella to survive in some brands of home-brew kits. Initially inoculated at $6-7 \log \mathrm{CFU} / \mathrm{mL}$, cell counts of both pathogens were reduced to $<0.3-1.85 \log \mathrm{CFU} / \mathrm{mL}$ after 10-14 days of fermentation in most brands, but alarmingly the numbers of Salmonella and STEC increased within one day and remained stable throughout the 14-day fermentation period in three brands of kombucha kits. Although both microorganisms were inoculated at levels much higher than what would be expected to be present as a result of natural contamination, the study highlights the requirement for strict hygiene and sanitary practices during kombucha brewing. 
Table 3. HACCP-based risk analysis of kombucha production (adapted from [18,117]).

\begin{tabular}{|c|c|c|c|c|}
\hline Step & Procedure & Hazard Type & Potential Hazard & Preventative Measure \\
\hline 1 & Boil water & Biological & Presence of pathogens in water & Boil water to kill pathogens \\
\hline 2 & $\begin{array}{l}\text { Dissolve sugar and steep tea in } \\
\text { boiled water. Cool heated tea. }\end{array}$ & Biological & $\begin{array}{l}\text { Introduction of contaminants prior } \\
\text { to fermentation }\end{array}$ & $\begin{array}{l}\text { Use clean and sanitised utensils and vessels. Ensure fermentation and } \\
\text { preparation areas are clean and sanitary. Cover fermentation vessel } \\
\text { with a porous cloth. Cool tea to } 20^{\circ} \mathrm{C} \text { within } 2 \mathrm{~h} \text { and start } \\
\text { fermentation as soon as possible. }\end{array}$ \\
\hline 3 & $\begin{array}{l}\text { Inoculate kombucha with SCOBY } \\
\text { and liquid kombucha }\end{array}$ & Biological & $\begin{array}{l}\text { Use of contaminated SCOBY or liquid } \\
\text { kombucha inoculum }\end{array}$ & $\begin{array}{l}\text { Use a commercial culture for first fermentation. Do not reuse a } \\
\text { culture with signs of mould contamination. Do not reuse a culture } \\
\text { which did not reach a pH of } \leq 4.2 \text { in a previous fermentation. }\end{array}$ \\
\hline \multirow{4}{*}{4} & \multirow{4}{*}{ Ferment for 7-10 days } & Biological & $\begin{array}{l}\text { Introduction or growth of contaminants } \\
\text { during fermentation }\end{array}$ & $\begin{array}{l}\text { Ensure fermentation areas are clean and sanitary. Cover fermentation } \\
\text { vessel with a porous cloth. Ferment aerobically to ensure acetic acid } \\
\text { production and ferment until a } \mathrm{pH} \leq 4.2 \text { is reached }\end{array}$ \\
\hline & & Chemical & $\begin{array}{l}\text { Leaching of chemical contaminants from } \\
\text { fermentation vessel due to low } \mathrm{pH} \text { of kombucha }\end{array}$ & $\begin{array}{l}\text { Use food-grade fermentation vessels such as glass, stainless steel, } \\
\text { high-density polyethylene (HDPE) or propylene (PP) }\end{array}$ \\
\hline & & Chemical & $\begin{array}{l}\text { Excessive production of organic acids due to } \\
\text { prolonged fermentation }\end{array}$ & $\begin{array}{l}\text { Stop fermentation before excess acid is produced. The } \mathrm{pH} \text { of the final } \\
\text { product should be } \geq 2.5\end{array}$ \\
\hline & & Chemical & $\begin{array}{l}{ }^{1} \text { Excessive production of ethanol due to } \\
\text { prolonged fermentation }\end{array}$ & $\begin{array}{l}\text { Stop fermentation before excess ethanol is produced OR allow } \\
\text { fermentation to proceed and include an additional manufacturing } \\
\text { step to reduce ethanol (e.g., distillation) }\end{array}$ \\
\hline 5 & $\begin{array}{l}\text { Remove SCOBY. Filter kombucha } \\
\text { (optional) }\end{array}$ & Biological & $\begin{array}{l}\text { Contamination of kombucha. Contamination of } \\
\text { SCOBY if not stored/re-used correctly }\end{array}$ & $\begin{array}{c}\text { Use clean and sanitised utensils and vessels. Ensure fermentation and } \\
\text { preparation areas are clean and sanitary. Use SCOBY in new } \\
\text { kombucha fermentation or store refrigerated in fresh sweetened tea } \\
\text { until use. }\end{array}$ \\
\hline 6 & Refrigerate & Biological & $\begin{array}{l}\text { Continued fermentation and production of } \\
\text { excess alcohol and acetic acid }\end{array}$ & Refrigerate at $4{ }^{\circ} \mathrm{C}$ to prevent continued fermentation \\
\hline $7 \mathrm{~A}$ & Consume at home & Chemical & $\begin{array}{l}\text { Excess consumption could result in toxicity } \\
\text { or acidosis }\end{array}$ & $\begin{array}{c}\text { Ensure } \mathrm{pH} \text { of final product is } \geq 2.5 \text {. Do not consume more than the } \\
\text { daily recommended amount. }\end{array}$ \\
\hline \multirow{2}{*}{ 7B } & \multirow{2}{*}{ Package for retail sale } & Chemical & $\begin{array}{l}\text { Leaching of chemical contaminants from } \\
\text { fermentation vessel due to low } \mathrm{pH} \text { of kombucha }\end{array}$ & Use suitable food-grade packaging materials \\
\hline & & Biological & $\begin{array}{l}\text { Introduction of contaminants from } \\
\text { packaging materials }\end{array}$ & Ensure packaging materials are clean and sanitised \\
\hline
\end{tabular}

${ }^{1}$ Applicable to commercial kombucha producers where ethanol levels may be required to be below a specified limit to be classed as non-alcoholic. 
In terms of chemical hazards, metabolic acidosis is a concern associated with kombucha consumption. Such a condition results from an accumulation of organic acids in the blood, a potentially fatal situation, particularly for those susceptible to acidosis [18]. In Iowa in 1995, two patients presented with severe metabolic acidosis and elevated blood lactic acid levels. Subsequent investigations showed that patient 1 had consumed approximately $4 \mathrm{oz}(125 \mathrm{~mL})$ of 7-day-fermented kombucha daily for the previous two months, while patient 2 had recently increased their daily consumption level and fermentation time to $12 \mathrm{oz}$ (375 $\mathrm{mL}$ ) and 14 days, respectively. The pellicles used by each patient were derived from the same mother pellicle; however, the microbiological analysis showed that pathogenic or toxin-producing microorganisms were not detected, and a causal relationship between kombucha consumption and the patients' elevated blood acid levels could not be definitively established. [114]. A prolonged fermentation period may result in overproduction of organic acids that pose a possible hazard to the consumer; thus, it is recommended that the fermentation time does not exceed ten days, with a desired final $\mathrm{pH}$ of $\geq 2.5$ [18,117]. As is the case with any food or beverage, excess consumption may lead to health problems; thus, kombucha should be consumed in moderation. Alcohol produced during kombucha fermentation can also be classed as a potential chemical hazard, particularly for at-risk populations such as children and pregnant women, for whom even low levels of alcohol consumption can have severe consequences [118,119]. In general, no measures are taken to reduce ethanol production during home brewing of kombucha; however, consumers should be aware of the potentially high alcohol levels in such brews. As commercial kombucha producers often require ethanol contents to be below a specified threshold for the beverage to be classed as non-alcoholic, the fermentation may be stopped after a specified period or the alcohol may be removed post-fermentation. Kombucha is a raw product, and accordingly there is a risk of continued fermentation and subsequent increases in organic acids and ethanol levels if the beverage is not refrigerated. Commercial producers may opt to include a pasteurisation step post-fermentation; however, most choose not to so as to retain the status as a 'raw' and accordingly 'healthier' product. Chemical contamination of kombucha may also occur if the fermentation is performed in unsuitable containers or vessels. Examples of food-grade containers suitable for kombucha production include those made from glass, stainless steel, high-density polyethylene (HDPE) or propylene (PP), while lead-containing materials such as ceramic or crystal should be avoided due to the risk of leaching toxic constituents from the container. Such an incident has been reported, with a married couple requiring chelation therapy for lead poisoning after daily consumption of kombucha for six months; the patients had brewed the kombucha tea in a ceramic pot, leading clinicians to hypothesise that the acidic tea had leached the heavy metal from the internal pot glazing [120]. However, such an occurrence is rare, with a similar situation not having been reported in the literature since [18].

\section{Kombucha Market}

\subsection{Market Analysis and Current Trends}

The global kombucha market stood at USD 1.85 billion in 2019 and is forecasted to increase to USD 10.45 billion by 2027, a projected compound annual growth rate (CAGR) of 23.2\%. North America dominated the global market in 2019, with a revenue share of approximately 52\%, while Europe is set to hold the second-largest market share in the coming years. In addition, substantial market growth is also being witnessed in AsiaPacific, the Middle East and Africa [12]. Formed in 2012, the Kombucha Brewers Institution (KBI) is a non-profit trade association of commercial kombucha brewers globally that strives to advance the industry through research, communication and legislation. As of December 2021, 215 commercial kombucha companies across the globe were registered with KBI, with the majority in North America (69.8\%), followed by Europe (16.3\%) (Figure 3). Unchanged from 2019, the numbers of registered kombucha companies in North America, Latin America, Asia-Pacific and Europe are dominated by Western USA, Mexico, Australia and Spain, respectively. In recent times, there has been increased interest from leading beverage 
companies seeking to expand their product portfolio and capitalise on the significant growth of the kombucha market. In 2016, PepsiCo acquired California-based company KeVita, a leading fermented beverage company that currently has 4 product lines (Master Brew Kombucha, Sparkling Probiotic Drink, Apple Cider Vinegar Tonic and Prebiotic Shots) spanning 28 flavours [121]. In June 2018, Clearly Kombucha was acquired by Molson Coors Brewing Company, a strategic step to strengthen the company's non-alcoholic beverage offering [122]. Coca-Cola added its first line of kombucha products in 2018 by acquiring Organic and Raw Trading Co. (producers of MOJO Kombucha), adding to its ever-increasing Australian beverage portfolio of 165 products and 25 brands at the time [123]. Coca-Cola's continued interest in the kombucha market resulted in a \$20 million equity investment in Health-Ade Kombucha in 2019 [124], a company that later sold a controlling stake to longstanding partner First Bev [125]. In 2018, Peet's Coffee (a USA company producing ready-to-drink (RDT) coffee) acquired a majority stake in Revive Kombucha for an undisclosed amount [126].

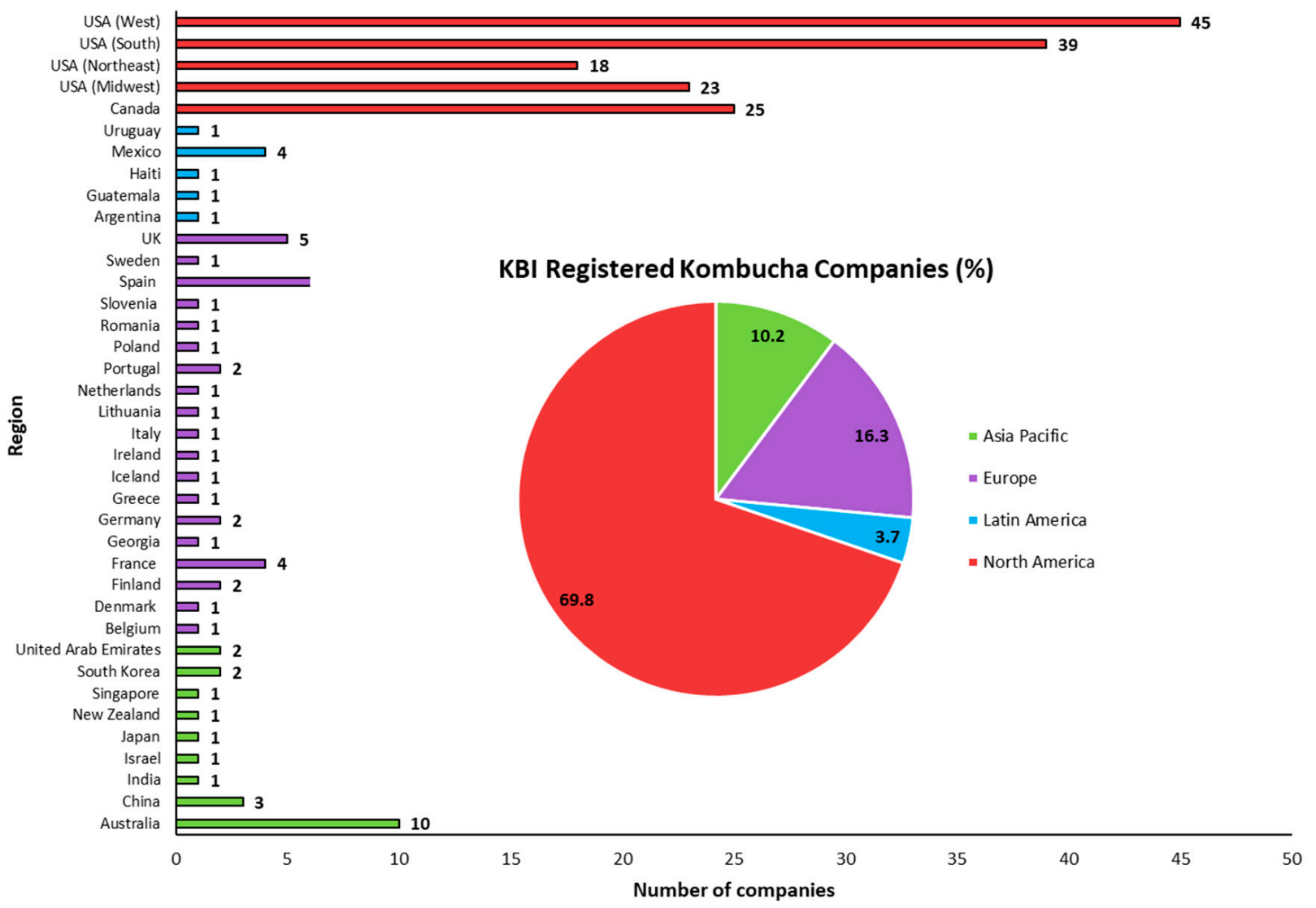

Figure 3. Number of Kombucha Brewers International (KBI) registered companies and their respective regions. Data correct as of December 2021.

Several trends have been highlighted as driving factors for the significant growth in the kombucha market. Recently, consumer preference has shifted towards low or non-alcoholic drinks due to the mortality rate associated with harmful alcohol consumption [127]. Consumers are adopting healthier lifestyles, and the surging popularity of fermented kombucha beverages is further encouraging this shift. The rising popularity of functional beverages has also contributed towards increased interest in kombucha, with functional beverages holding a $76.4 \%$ share in the overall beverage market in the U.S in 2017 [12] and the European functional beverage market projected to increase by $6.5 \%$ from 2021-2025 [128]. Although the COVID-19 pandemic negatively impacted many industries, the fermented beverage market witnessed a slight increase as consumer demand shifted towards immunity-boosting beverages amid rising rates of coronavirus infection; for ex- 
ample, WonderBrew Kombucha (Malaysia) had surpassed its 2018 sales figures by June of 2019 just by increasing its online presence. Additionally, kombucha beverages are now more readily available through various distribution channels, including supermarkets and convenience stores, health stores and online retailers. The range of innovative kombucha flavours available is also attracting increased consumer attention, with companies offering novel flavours such as lavender, watermelon, peach and passionfruit alongside their original kombucha beverages [12].

\subsection{Commercial Kombucha Products}

Table 4 provides an overview of some global commercial kombucha brands and their product details, data which were collected from company websites or online retail sites. As can be seen, the main product claims made are 'raw', 'organic', 'vegan', 'non-GMO' and 'gluten-free', while most have similar base ingredients of filtered or purified water, black or green tea, cane sugar and kombucha cultures. According to the IFIC Food and Health Survey 2021 [129], 72\% of consumers are attempting to limit or avoid sugar, with $20 \%$ doing so based on medical advice. Accordingly, 'sweetness reinvented' is one of the 10 Key Trends forecasted for 2022 [130], with some kombucha producers already embracing this and providing 'zero-' or low-sugar options or replacing traditional sugar with artificial sweeteners such as stevia leaves or erythritol. In such cases, sugar is still added at the beginning as a carbon source for the kombucha culture but is depleted during fermentation, with sweeteners added to replace the sweet taste (Gutsy Kombucha, KÖE Kombucha, Kevita MasterBrew, The GUTsy Captain Kombucha, Remedy Kombucha). Most producers offer kombucha beverages in a range of flavours, with fruits (e.g., strawberry, raspberry, watermelon, blueberry, lemon) and herbs (e.g., ginger, mint, sage, rosemary) and combinations thereof the most common options. Along with different flavours, some manufacturers offer different product ranges to provide beverages that are distinctly different from traditional kombucha. For example, GT's Living Energy offers three different classes of kombucha: the 'classic' range, which encompasses traditional kombucha in a range of flavours; the 'synergy' range, which provides a smoother taste to new drinkers; 'hard' kombucha, which includes more sophisticated flavours and has an ABV (\% v/v) of 3\%. In addition, Brew Dr. and Aqua ViTea have capitalised on the current cannabidiol (CBD) trend in the USA, both launching a CBD-infused kombucha beverage range.

Of the 26 kombucha products surveyed, most were marketed as raw, with just one (Biona Organic, Surrey, UK) stating that the beverage underwent pasteurisation. Several brands also add additional live cultures, with Bacillus spp. appearing to be a popular choice amongst kombucha producers. Specifically, both GT's Living Energy Kombucha and MOJO Kombucha use Bacillus coagulans GBI-30 6086, while Kevita MasterBrew Kombucha utilises B. coagulans MTCC 5856, commercially available strains that are well-documented in terms of their resistance to low $\mathrm{pH}$, making them excellent candidates for survival in the acidic kombucha environment [131-133]. Interestingly, Majeed et al. [134] recently highlighted the remarkable survival of $B$. coagulans MTCC 5856 in tea (99.76\% viability) and additionally demonstrated that inclusion of the strain after brewing did not significantly impact the sensory profile of the beverage. Other live cultures commonly used in commercial kombucha products include Bacillus subtilis, Lb. plantarum and S. boulardii. 
Table 4. Examples of commercial kombucha products on the market.

\begin{tabular}{|c|c|c|c|c|c|c|c|}
\hline Brand Name & $\begin{array}{l}\text { Country of } \\
\text { Production }\end{array}$ & $\begin{array}{c}\text { No. of } \\
\text { Products/Flavours } \\
\text { Available }\end{array}$ & Base Ingredients & $\begin{array}{c}\text { Calories } \\
\text { (kcal/100 mL) }\end{array}$ & $\begin{array}{c}\text { Sugar } \\
(\mathrm{g} / 100 \mathrm{~mL})\end{array}$ & $\begin{array}{l}\text { Alcohol } \\
(\% v / v)\end{array}$ & Product Claims \\
\hline $\begin{array}{l}\text { GT's Living Foods } \\
\text { Kombucha }\end{array}$ & USA & $\begin{array}{l}50 \text { (12 Classic; } 31 \\
\text { Synergy; } 7 \text { Hard) }\end{array}$ & $\begin{array}{l}\text { Black tea, green tea, cane sugar, kiwi } \\
\text { juice, live cultures (S. boulardii: } 4 \text { billion } \\
\text { CFU, Lactobacillus bacterium: } 4 \text { billion } \\
\text { CFU, Bacillus coagulans GBI-306086: } \\
\text { 1 billion CFU) }\end{array}$ & $\leq 31$ & $2.5-4.2$ & $\begin{array}{l}\text { Classic: } 0.5-1 \% ; \\
\text { Hard: } 3 \% \text {; Synergy: } \\
\quad<0.5 \%\end{array}$ & $\begin{array}{l}\text { Organic; Vegan; } \\
\text { Non-GMO; } \\
\text { Gluten-Free; Raw }\end{array}$ \\
\hline $\begin{array}{l}\text { Wonder Drink } \\
\text { Kombucha }\end{array}$ & USA & 5 & $\begin{array}{c}\text { Filtered water, green tea, black tea, } \\
\text { kombucha culture (yeast and bacteria), } \\
\text { cane sugar, prebiotic corn fibre } \\
\text { (xylo-oligosaccharides), natural flavour, } \\
\text { stevia leaf extract }\end{array}$ & $\leq 14$ & $2.3-2.8$ & $<0.5 \%$ & $\begin{array}{l}\text { Organic; Vegan; } \\
\text { Non-GMO; Gluten-free; } \\
\text { BPA free; Low-sugar; } \\
\text { Non-alcoholic; Raw }\end{array}$ \\
\hline $\begin{array}{l}\text { Humm } \\
\text { Kombucha }\end{array}$ & USA & $\begin{array}{l}24 \text { (13 Original; } 6 \\
\text { Zero; } 5 \text { Whole } 30 \\
\text { Approved) }\end{array}$ & $\begin{array}{c}\text { Filtered water, green tea, black tea, } \\
\text { white grape juice, cane sugar, live } \\
\text { kombucha cultures, natural flavours, } \\
\text { Bacillus subtilis ( } 2 \text { billion CFU), } \\
\text { vitamin B12 }\end{array}$ & $\leq 18$ & $2.4-3.9$ & $<0.5 \%$ & $\begin{array}{c}\text { Organic; Vegan; } \\
\text { Non-GMO; Gluten-free; } \\
\text { Keto-friendly; } \\
\text { Non-alcoholic; Raw }\end{array}$ \\
\hline $\begin{array}{l}\text { Rowdy Mermaid } \\
\text { Kombucha }\end{array}$ & USA & 9 & $\begin{array}{c}\text { Filtered water, green tea, black tea, cane } \\
\text { sugar, live cultures } \\
\text { (Lactobacillus plantarum) }\end{array}$ & $\leq 14$ & $2.5-2.8$ & $<0.5 \%$ & $\begin{array}{l}\text { Vegan; Non-GMO; } \\
\text { Gluten-free; } \\
\text { Non-alcoholic; Raw }\end{array}$ \\
\hline $\begin{array}{c}\text { Kevita Master Brew } \\
\text { Kombucha }\end{array}$ & USA & 15 & $\begin{array}{l}\text { Filtered water, kombucha culture, black } \\
\text { tea, green tea, natural flavour, cane } \\
\text { sugar, B. coagulans LactoSpore MTCC } \\
\text { 5856, black tea essence, caffeine (green } \\
\text { coffee bean extract), stevia leaf extract }\end{array}$ & $\leq 17$ & $3.3-3.6$ & $<0.5 \%$ & $\begin{array}{l}\text { Organic; Non-GMO; } \\
\quad \text { Kosher; } \\
\text { Non-alcoholic; Raw }\end{array}$ \\
\hline
\end{tabular}


Table 4. Cont.

\begin{tabular}{|c|c|c|c|c|c|c|c|}
\hline Brand Name & $\begin{array}{l}\text { Country of } \\
\text { Production }\end{array}$ & $\begin{array}{c}\text { No. of } \\
\text { Products/Flavours } \\
\text { Available }\end{array}$ & Base Ingredients & $\begin{array}{c}\text { Calories } \\
\text { (kcal/100 mL) }\end{array}$ & $\begin{array}{l}\text { Sugar }(g / 100 \\
\mathrm{mL})\end{array}$ & $\begin{array}{l}\text { Alcohol } \\
(\% v / v)\end{array}$ & Product Claims \\
\hline $\begin{array}{l}\text { Brew Dr. } \\
\text { Kombucha }\end{array}$ & USA & $\begin{array}{l}13 \text { (10 Classic; } 3 \\
\text { Tranquil (CBD)) }\end{array}$ & $\begin{array}{l}\text { Filtered water, green tea, cane sugar, } \\
\text { live kombucha culture (yeast, bacteria) }\end{array}$ & $\leq 19$ & $2.9-3.6$ & $<0.5 \%$ & $\begin{array}{l}\text { Organic; Non-GMO; } \\
\text { Gluten-free; Kosher; } \\
\text { Alcohol-extracted; Raw }\end{array}$ \\
\hline Clearly Kombucha & USA & 4 & $\begin{array}{l}\text { Filtered water, active culture, cane } \\
\text { sugar, black tea, green tea, ginger root, } \\
\text { natural flavours, fruit and vegetable } \\
\text { juice, live probiotic (B. coagulans, } \\
\text { I billion CFU) }\end{array}$ & $\leq 5$ & $0.0-1.2$ & $<0.5 \%$ & $\begin{array}{l}\text { Organic; Non-GMO; } \\
\text { Gluten-free; Kosher; } \\
\text { Non-alcoholic; Raw }\end{array}$ \\
\hline $\begin{array}{l}\text { Health-Ade } \\
\text { Kombucha }\end{array}$ & USA & $\begin{array}{l}22 \text { (15 Original; } 7 \\
\text { Health-Ade Plus) }\end{array}$ & $\begin{array}{c}\text { Filtered water, green tea, black tea, cane } \\
\text { sugar, live kombucha cultures (yeast } \\
\text { and bacteria) }\end{array}$ & $\leq 17$ & $2.7-3.6$ & Trace amounts & $\begin{array}{l}\text { Organic; Vegan; } \\
\text { non-GMO; } \\
\text { Gluten-free; Raw }\end{array}$ \\
\hline $\begin{array}{l}\text { Aqua ViTea } \\
\text { Kombucha }\end{array}$ & USA & $\begin{array}{l}11 \text { (9 Original; } \\
2 \text { CBD) }\end{array}$ & $\begin{array}{l}\text { Filtered water, black tea, green tea, cane } \\
\text { sugar, kombucha culture }\end{array}$ & $\leq 15$ & $1.3-2.1$ & $<0.5 \%$ & $\begin{array}{c}\text { Organic; Vegan; } \\
\text { Non-GMO; Gluten-free; } \\
\text { Paleo; } \\
\text { Alcohol-extracted; Raw }\end{array}$ \\
\hline $\begin{array}{l}\text { Gutsy } \\
\text { Kombucha }\end{array}$ & Canada & $\begin{array}{l}8 \text { (6 Classic; } \\
2 \text { No Sugar) }\end{array}$ & $\begin{array}{l}\text { Filtered water, black tea, cane sugar, } \\
\text { living cultures (bacteria and yeast) }\end{array}$ & $\leq 14$ & $0.0-3.7$ & $<0.5 \%$ & $\begin{array}{l}\text { Organic; Vegan; } \\
\text { Non-GMO; } \\
\text { Gluten-free; Raw }\end{array}$ \\
\hline $\begin{array}{l}\text { Hoochy Booch } \\
\text { Kombucha }\end{array}$ & Canada & 10 & $\begin{array}{l}\text { Filtered water, green tea, cane sugar, } \\
\text { kombucha culture }\end{array}$ & 8 & 2.1 & Trace amounts & $\begin{array}{l}\text { Organic; Vegan; Gluten } \\
\text { free; Raw }\end{array}$ \\
\hline $\begin{array}{l}\text { Vitae } \\
\text { Kombucha }\end{array}$ & Spain & 9 & $\begin{array}{l}\text { Volcanic mineral water, green tea, cane } \\
\text { sugar, kombucha culture }\end{array}$ & $\leq 16$ & $1.6-3.7$ & $<0.5 \%$ & $\begin{array}{l}\text { Organic; Vegan; Gluten } \\
\text { free; Lactose-free; Raw }\end{array}$ \\
\hline $\begin{array}{l}\text { The GUTsy Captain } \\
\text { Kombucha }\end{array}$ & Portugal & $\begin{array}{l}15 \text { (9 Traditional; } \\
6 \text { Zero) }\end{array}$ & $\begin{array}{l}\text { Filtered water, cane sugar, green tea } \\
(0.4 \%) \text {, stevia leaves, kombucha } \\
\text { cultures, Bacillus coagulans }\end{array}$ & $\leq 18$ & $0.0-4.4$ & $<0.5 \%$ & $\begin{array}{l}\text { Organic; Vegan; Gluten } \\
\text { free; Low-calorie; } \\
\text { Non-alcoholic; Raw }\end{array}$ \\
\hline
\end{tabular}


Table 4. Cont.

\begin{tabular}{|c|c|c|c|c|c|c|c|}
\hline Brand Name & $\begin{array}{l}\text { Country of } \\
\text { Production }\end{array}$ & $\begin{array}{c}\text { No. of } \\
\text { Products/Flavours } \\
\text { Available }\end{array}$ & Base Ingredients & $\begin{array}{c}\text { Calories } \\
\text { (kcal/100 mL) }\end{array}$ & $\begin{array}{l}\text { Sugar } \\
(\mathrm{g} / 100 \mathrm{~mL})\end{array}$ & $\begin{array}{l}\text { Alcohol } \\
(\% v / v)\end{array}$ & Product Claims \\
\hline SynerChi Kombucha & Ireland & $\begin{array}{l}11 \text { (6 Classic } \\
\text { Kombucha Bottles; } \\
3 \text { Kombucha Cans; } \\
2 \text { Kombucha Shots) }\end{array}$ & $\begin{array}{l}\text { Filtered water, sencha green tea, golden } \\
\text { cane sugar, kombucha cultures }\end{array}$ & $\leq 38$ & $0.0-4.5$ & $<0.5 \%$ & $\begin{array}{l}\text { Organic; Vegan; Gluten } \\
\text { free; Dairy free; Soy-free; } \\
\text { Non-alcoholic; Raw }\end{array}$ \\
\hline $\begin{array}{l}\text { Holo } \\
\text { Kombucha }\end{array}$ & Ireland & 2 & $\begin{array}{l}\text { Filtered purified water, green tea, black } \\
\text { tea, sugar, kombucha cultures }\end{array}$ & $\leq 7$ & 3.1 & $<1 \%$ & $\begin{array}{l}\text { Organic; Vegan; } \\
\text { Non-GMO; Gluten free; } \\
\text { Dairy free; Raw }\end{array}$ \\
\hline $\begin{array}{l}\text { Leave Your Sword } \\
\text { Kombucha }\end{array}$ & Netherlands & 7 & $\begin{array}{c}\text { Filtered water, tea, beetroot sugar, } \\
\text { kombucha culture }\end{array}$ & $\mathrm{n} / \mathrm{a}$ & 4.5 & $2.5 \%$ & Raw \\
\hline Equinox Kombucha & UK & 12 & $\begin{array}{l}\text { Pure spring water, chun-mee green tea, } \\
\text { raw cane sugar, kombucha cultures }\end{array}$ & $\leq 18$ & $2.5-4.3$ & $<0.5 \%$ & $\begin{array}{l}\text { Organic; Vegan; Gluten } \\
\text { free; Plant-based; } \\
\text { Non-alcoholic; Raw }\end{array}$ \\
\hline $\begin{array}{l}\text { Biona } \\
\text { Kombucha }\end{array}$ & UK & 3 & $\begin{array}{c}\text { Tea herbal extract (natural mineral } \\
\text { water, green tea, black tea, mate leaves, } \\
\text { lime blossom, lemon verbena, } \\
\text { cornflower blossom, lemon balm, mint, } \\
\text { nettle, woodruff, elder blossom, } \\
\text { raspberry leaves, marigold blossom, } \\
\text { blackberry leaves, liquorice root), raw } \\
\text { cane sugar, kombucha cultures, natural } \\
\text { carbon dioxide }\end{array}$ & $\leq 18$ & 4.7 & $<0.5 \%$ & $\begin{array}{l}\text { Organic; Vegan; } \\
\text { Non-alcoholic; } \\
\text { Pasteurised }\end{array}$ \\
\hline $\begin{array}{l}\text { MOJO } \\
\text { Kombucha }\end{array}$ & Australia & $\begin{array}{l}15 \text { (6 Activated } \\
\text { Kombucha; } 4 \text { Gut } \\
\text { Shot; } 3 \text { Kombucha } \\
\text { Soda; } 2 \text { Superbooch) }\end{array}$ & $\begin{array}{l}\text { Water, sugar, tea, kombucha culture, } \\
\text { B. coagulans GBI-30 } 6086 \text { (1 billion CFU) }\end{array}$ & $\leq 22$ & $1.7-2.4$ & $<0.5 \%$ & $\begin{array}{l}\text { Organic; Vegan; } \\
\text { Low-sugar; } \\
\text { Non-alcoholic; Raw }\end{array}$ \\
\hline Remedy Kombucha & Australia & 13 & $\begin{array}{l}\text { Sparkling water, sugar, black tea, green } \\
\text { tea, wild kombucha culture, erythritol, } \\
\text { steviol glycosides }\end{array}$ & 4 & 0.0 & $<0.5 \%$ & $\begin{array}{l}\text { Organic; Vegan; Gluten } \\
\text { free; Non-alcoholic; } \\
\text { Raw; Halal }\end{array}$ \\
\hline $\begin{array}{l}\text { Naughty Booch } \\
\text { Kombucha }\end{array}$ & Australia & 2 & $\begin{array}{l}\text { Kombucha apple cider blend, lime juice, } \\
\text { monk fruit, natural flavours }\end{array}$ & $\leq 36$ & $1.4-2.1$ & $4.6 \%$ & Vegan; Low-sugar \\
\hline
\end{tabular}


Table 4. Cont.

\begin{tabular}{|c|c|c|c|c|c|c|c|}
\hline Brand Name & $\begin{array}{l}\text { Country of } \\
\text { Production }\end{array}$ & $\begin{array}{c}\text { No. of } \\
\text { Products/Flavours } \\
\text { Available }\end{array}$ & Base Ingredients & $\begin{array}{c}\text { Calories } \\
\text { (kcal/100 mL) }\end{array}$ & $\begin{array}{c}\text { Sugar }(g / 100 \\
\mathrm{mL})\end{array}$ & $\begin{array}{l}\text { Alcohol } \\
(\% v / v)\end{array}$ & Product Claims \\
\hline $\begin{array}{l}\text { Swig } \\
\text { Kombucha }\end{array}$ & $\begin{array}{c}\text { New } \\
\text { Zealand }\end{array}$ & 4 & $\begin{array}{l}\text { Purified Wanaka alpine water, sugar, } \\
\text { green tea, black tea, kombucha culture }\end{array}$ & $\mathrm{n} / \mathrm{a}$ & $\mathrm{n} / \mathrm{a}$ & $\mathrm{n} / \mathrm{a}$ & Organic; Raw \\
\hline $\begin{array}{l}\text { BomBooch } \\
\text { Kombucha }\end{array}$ & China & 6 & $\begin{array}{l}\text { Filtered water, green tea, black Ceylon } \\
\text { tea, raw unrefined cane sugar, } \\
\text { SCOBY culture }\end{array}$ & $\leq 19$ & 1.7 & $<0.5 \%$ & Raw \\
\hline
\end{tabular}

n/a: information not available. 
As shown in Table 4, most kombucha beverages have an $\mathrm{ABV}$ value of $<0.5 \%$, keeping in line with guidelines regarding the classification of non-alcoholic beverages, although these vary depending on geographical region. Some manufacturers have chosen to embrace the alcoholic nature of kombucha fermentation, such as GT's Living Energy Hard Kombucha ( $3 \% \mathrm{ABV})$, Leave Your Sword Kombucha (2.6\% ABV) and Naughty Booch Alcoholic Kombucha (4.6\% ABV). There have been several controversies surrounding the alcohol contents of commercial kombucha products, with some found to contain levels exceeding values stated on the label. As such, these products would no longer be classed as nonalcoholic and would be subject to alcohol taxation. As already mentioned, due to the raw nature of the kombucha product, there is a possibility of fermentation post-manufacture; therefore, although the alcohol content may be below the threshold limit upon leaving the producer, the $\mathrm{ABV}$ may exceed the permissible limit if not correctly stored during distribution. A recent study by Jang et al. [135] measured the ethanol contents of 684 kombucha samples collected from processers and purchased from retailers in British Columbia, where beverages $>1 \% \mathrm{ABV}$ are considered alcoholic. They found that $31.5 \%$ of samples contained ethanol levels that exceeded the regulatory limits of $1 \% \mathrm{ABV}$, while four teas $(0.6 \%)$ were reported to contain $>3 \% \mathrm{ABV}$, more than five times their stated alcohol content. This is neither an uncommon nor a recent phenomenon, with kombucha products being recalled worldwide since 2010 due to false advertising of alcohol contents [136-138]. The KBI organisation is actively pursuing legislation (H.R.2124-117th Congress) that would see the level at which taxation would occur increase from $0.5 \%$ to $1.25 \% \mathrm{ABV}$, while still abiding by the health and safety requirements applicable to non-alcoholic beverages [139].

\section{Conclusions and Future Perspectives}

The global popularity of kombucha is rising significantly, with increases in both household and commercial production of the fermented tea. The beverage's microbiological, sensory, and functional compounds vary and are highly dependent on the substrate used, the fermentation conditions and the microbial diversity of the kombucha consortium. Sucrose and black or green tea are the primary fermentation substrates; however, the use of alternatives has been investigated. Different substrates can positively or negatively influence the kombucha beverage, affecting the microbial growth, metabolite production and functionality. Yeasts and $\mathrm{AAB}$ are the core microbiota of the kombucha community, while LAB have also been identified systematically. Microbial diversity at genus and species levels can vary between consortiums in different geographical regions and even within the same region. Yeasts play a key role in making substrates available to AAB through a mutualistic relationship, while $\mathrm{AAB}$ utilises such substrates to produce organic acids and other metabolites, which positively modify the environment for yeast. The emergence of culture-independent techniques has allowed for a deeper insight into the diversity of the complex microbial community and the interactions taking place therein. The use of defined starter cultures to reproduce a stable kombucha community is a promising alternative to traditional kombucha fermentation; however, this area of research remains largely understudied. The safety of kombucha is typically guaranteed by its low $\mathrm{pH}$; however, producers and consumers should still be aware of the risks, such as biological contamination and secondary fermentation. There is a widespread belief that kombucha is a health product; however, its purported benefits have been investigated using animal models and human cell lines, while little in the way of research on kombucha's function in human subjects has been performed to date. Future studies should focus on the modulation of kombucha's sensory and functional characteristics through a deeper understanding of the communication and interactions between members of the microbial community. In addition, research efforts should be directed towards the use of defined starter cultures, particularly to facilitate a shift toward industrial-scale production of kombucha.

Author Contributions: Conceptualisation, E.K.A.; investigation, L.M.N.; writing-original draft preparation, L.M.N. and K.M.L.; writing-review and editing, L.M.N., K.M.L., A.W.S. and E.K.A.; supervision, E.K.A. All authors have read and agreed to the published version of the manuscript. 
Funding: This research received no external funding.

Institutional Review Board Statement: Not applicable.

Informed Consent Statement: Not applicable.

Data Availability Statement: Not applicable.

Acknowledgments: This work has been sponsored by and performed in collaboration with ABInBev's GITeC - The Core Global Research and Development Centre. The authors would like to thank Stuart Wilkinson, Luk Daenan and Patrick O' Riordan for their support of this work. The authors would also like to thank William Organ and Audrey Byrne for their assistance throughout the writing of this manuscript.

Conflicts of Interest: The authors declare no conflict of interest.

\section{References}

1. Soares, M.G.; de Lima, M.; Reolon Schmidt, V.C. Technological aspects of kombucha, its applications and the symbiotic culture (SCOBY), and extraction of compounds of interest: A literature review. Trends Food Sci. Technol. 2021, 110, 539-550. [CrossRef]

2. Greenwalt, C.J.; Steinkraus, K.H.; Ledford, R.A. Kombucha, the fermented tea: Microbiology, composition, and claimed health effects. J. Food Prot. 2000, 63, 976-981. [CrossRef] [PubMed]

3. Kim, J.; Adhikari, K. Current trends in kombucha: Marketing perspectives and the need for improved sensory research. Beverages 2020, 6, 15. [CrossRef]

4. Liu, C.; Hsu, W.; Lee, F.; Liao, C. The isolation and identification of microbes from a fermented tea beverage, Haipao and their interactions during Haipao fermentation. Food Microbiol. 1996, 13, 407-415. [CrossRef]

5. Mayser, P.; Fromme, S.; Leitzmann, G.; Gründer, K. The yeast spectrum of the 'tea fungus kombucha'. Mycoses 1995, 38, 289-295. [CrossRef] [PubMed]

6. Marsh, A.J.; Sullivan, O.O.; Hill, C.; Ross, R.P.; Cotter, P.D. Sequence-based analysis of the bacterial and fungal compositions of multiple kombucha (tea fungus) samples. Food Microbiol. 2014, 38, 171-178. [CrossRef]

7. Chakravorty, S.; Bhattacharya, S.; Chatzinotas, A.; Chakraborty, W.; Bhattacharya, D.; Gachhui, R. Kombucha tea fermentation: Microbial and biochemical dynamics. Int. J. Food Microbiol. 2016, 220, 63-72. [CrossRef]

8. Sievers, M.; Lanini, C.; Weber, A.; Schuler-Schmid, U.; Teuber, M. Microbiology and fermentation balance in a kombucha beverage obtained from a tea fungus fermentation. Syst. Appl. Microbiol. 1995, 18, 590-594. [CrossRef]

9. Jayabalan, R.; Malbaša, R.V.; Lončar, E.S.; Vitas, J.S.; Sathishkumar, M. A review on kombucha tea-microbiology, composition, fermentation, beneficial effects, toxicity, and tea fungus. Compr. Rev. Food Sci. Food Saf. 2014, 13, 538-550. [CrossRef]

10. Villarreal-Soto, S.A.; Beaufort, S.; Bouajila, J.; Souchard, J.P.; Taillandier, P. Understanding kombucha tea fermentation: A review. J. Food Sci. 2018, 83, 580-588. [CrossRef] [PubMed]

11. Watawana, M.I.; Jayawardena, N.; Gunawardhana, C.B.; Waisundara, V.Y. Health, wellness, and safety aspects of the consumption of kombucha. J. Chem. 2015, 2015, 591869. [CrossRef]

12. Fortune Business Insights Kombucha Market Size, Share \& COVID-19 Impact Analysis, by Type (Natural and Flavored), Distribution Channel (Supermarkets/Hypermarkets, Convenience Stores, Health Stores, and Online Retail), and Regional Forecast, 2020-2027. Available online: https://www.fortunebusinessinsights.com/industry-reports/kombucha-market-100230 (accessed on 29 November 2021).

13. Kapp, J.M.; Sumner, W. Kombucha: A systematic review of the empirical evidence of human health benefit. Ann. Epidemiol. 2019, 30, 66-70. [CrossRef] [PubMed]

14. Srinivasan, R.; Smolinske, S.; Greenbaum, D. Probable gastrointestinal toxicity of kombucha tea: Is this beverage healthy or harmful? J. Gen. Intern. Med. 1997, 12, 643-645. [CrossRef] [PubMed]

15. Gedela, M.; Potu, K.C.; Gali, V.L.; Alyamany, K.; Jha, L.K. A case of hepatotoxicity related to kombucha tea consumption. SD Med. 2016, 69, 26-28.

16. Kole, A.; Jones, H.D.; Christensen, R.; Gladtsein, J. A case of kombucha tea toxicity. J. Intensiv. Care Med. 2009, 24, 205-207. [CrossRef] [PubMed]

17. Perron, A.; Patterson, J.; Yanofsky, N.N. Kombucha "mushroom" hepatotoxicity. Ann. Emerg. Med. 1995, 26, 660-661. [CrossRef] [PubMed]

18. Murphy, T.E.; Walia, K.; Farber, J.M. Safety aspects and guidance for consumers on the safe preparation, handling and storage of kombucha-A fermented tea beverage. Food Prot. Trends 2018, 38, 329-337.

19. Goh, W.N.; Rosma, A.; Kaur, B.; Fazilah, A.; Karim, A.A.; Bhat, R. Fermentation of black tea broth (kombucha): I. Effects of sucrose concentration and fermentation time on the yield of microbial cellulose. Int. Food Res. J. 2012, 19, 109-117.

20. Malbaša, R.; Lončar, E.; Djurić, M.; Došenović, I. Effect of sucrose concentration on the products of kombucha fermentation on molasses. Food Chem. 2008, 108, 926-932. [CrossRef] [PubMed]

21. Banerjee, S.; Chatterjee, J. Efficient extraction strategies of tea (Camellia sinensis) biomolecules. J. Food Sci. Technol. 2015, 52, 3158-3168. [CrossRef] [PubMed] 
22. Harbowy, M.E.; Balentine, D.A.; Davies, A.P.; Cai, Y. Tea chemistry. CRC Crit. Rev. Plant Sci. 1997, 16, 415-480. [CrossRef]

23. Roussin, M. Analyses of Kombucha Ffrments. Available online: https://research.kombuchabrewers.org/wp-content/uploads/ kk-research-files / analyses-of-kombucha-ferments.pdf (accessed on 21 November 2021).

24. Reiss, J. Influence of different sugars on the metabolism of the tea fungus. Z. Lebensm. Unters. Forsch. 1994, 198, 258-261. [CrossRef]

25. Malbaša, R.; Lončar, E.; Djurić, M. Comparison of the products of kombucha fermentation on sucrose and molasses. Food Chem. 2008, 106, 1039-1045. [CrossRef]

26. Muhialdin, B.J. Effects of sugar sources and fermentation time on the properties of tea fungus (kombucha) beverage. Int. Food Res. J. 2019, 26, 481-487.

27. Vohra, B.M.; Fazry, S.; Sairi, F.; Babul-airianah, O. Effects of medium variation and fermentation time on the antioxidant and antimicrobial properties of kombucha. Malays. J. Fundam. Appl. Sci. 2019, 15, 298-302. [CrossRef]

28. Cvetković, D.D.; Markov, S.L. Cultivation of tea fungus on malt extract medium. Acta Period. Technol. 2002, 33, 117-126. [CrossRef]

29. Malbaša, R.V.; Lončar, E.S.; Kolarov, L.J.A. Sucrose and inulin balance during tea fungus fermentation. Rom. Biotechnol. Lett. 2002, 7,573-576.

30. Lončar, E.S.; Malbaša, R.V.; Kolarov, L.A. Kombucha fermentation on raw extracts of different cultivars of Jerusalem artichoke. Acta Period. Technol. 2007, 38, 37-44. [CrossRef]

31. Francisco, Á.R.; Jose, R.M.; Igor, H. Development of a no added sugar kombucha beverage based on germinated corn. Int. J. Gastron. Food Sci. 2021, 24, 100355. [CrossRef]

32. Degirmencioglu, N.; Yildiz, E.; Sahan, Y.; Guldas, M.; Gurbuz, O. Impact of tea leaves types on antioxidant properties and bioaccessibility of kombucha. J. Food Sci. Technol. 2021, 58, 2304-2312. [CrossRef]

33. Tanticharakunsiri, W.; Mangmool, S.; Ochaikul, D. Characteristics and upregulation of antioxidant enzymes of kitchen mint and oolong tea kombucha beverages. J. Food Biochem. 2020, 45, 1-14. [CrossRef] [PubMed]

34. Tsuru, V.H.; Gomes, R.J.; Silva, J.R.; Prudencio, S.H.; Costa, G.N.; Spinosa, W.A. Physicochemical, antioxidant and sensory properties of kombucha beverages obtained from oolong or yerba mate tea fermentation. Res. Soc. Dev. 2021, 10, e62101118790. [CrossRef]

35. Gaggìa, F.; Baffoni, L.; Galiano, M.; Nielsen, D.S.; Jakobsen, R.R.; Castro-Mejía, J.L.; Bosi, S.; Truzzi, F.; Musumeci, F.; Dinelli, G.; et al. Kombucha beverage from green, black and rooibos teas: A comparative study looking at microbiology, chemistry and antioxidant activity. Nutrients 2019, 11, 1. [CrossRef] [PubMed]

36. Zou, C.; Li, R.; Chen, J.; Wang, F.; Gao, Y.; Fu, Y.; Xu, Y.; Yin, J. Zijuan tea-based kombucha: Physicochemical, sensorial, and antioxidant profile. Food Chem. 2021, 363, 3-10. [CrossRef] [PubMed]

37. Reiss, J. Der Teepilz und seine Stoffwechselproducte. Dtsch. Leb. 1987, 83, 286-290.

38. Velićanskí, A.S.; Cvetković, D.D.; Markov, S. Characteristics of kombucha fermentation on medicinal herbs from Lamiaceae family. Rom. Biotechnol. Lett. 2013, 18, 8034-8042.

39. Zhang, J.; Van Mullem, J.; Dias, D.R.; Schwan, R.F. The chemistry and sensory characteristics of new herbal tea-based kombuchas. J. Food Sci. 2021, 86, 740-748. [CrossRef]

40. Vitas, J.S.; Cvetanović, A.D.; Mašković, P.Z.; Švarc-Gajić, J.V.; Malbaša, R.V. Chemical composition and biological activity of novel types of kombucha beverages with yarrow. J. Funct. Foods 2018, 44, 95-102. [CrossRef]

41. Četojević-Simin, D.D.; Velićanski, A.S.; Cvetković, D.D.; Markov, S.L.; Mrdanović, J.Ž.; Bogdanović, V.V.; Šolajić, S.V. Bioactivity of lemon balm kombucha. Food Bioprocess Technol. 2012, 5, 1756-1765. [CrossRef]

42. Velićanski, A.S.; Cvetkovic, D.D.; Markov, S.L.; Tumbas Šaponjac, V.T.; Vulić, J.J. Antioxidant and antibacterial activity of the beverage obtained by fermentation of sweetened lemon balm (Melissa officinalis L.) tea with symbiotic consortium of bacteria and yeasts. Food Technol. Biotechnol. 2014, 52, 420-429. [CrossRef] [PubMed]

43. Vázquez-Cabral, B.D.; Rocha-Guzmán, N.E.; Gallegos-Infante, J.A.; González-Herrera, S.M.; González-Laredo, R.F.; Moreno-Jiménez, M.R.; Córdova-Moreno, I.T.S. Chemical and sensory evaluation of a functional beverage obtained from infusions of oak leaves (Quercus resinosa) inoculated with the kombucha consortium under different processing conditions. Nutrafoods 2014, 13, 169-178. [CrossRef]

44. Vázquez-Cabral, B.; Larrosa-Perez, M.; Gallegos-Infante, J.A.; Moreno-Jimenez, M.R.; Gonzalez-Laredo, R.; Rutiago-Quinones, J.G.; Gamboa-Gomez, C.I.; Rocha-Guzman, N.E. Oak kombucha protects against oxidative stress and inflammatory processes. Chem. Biol. Interact. 2017, 272, 1-9. [CrossRef] [PubMed]

45. Pure, A.E.; Pure, M.E. Antioxidant and antibacterial activity of kombucha beverages prepared using banana peel, common nettles and black tea infusions. Appl. Food Biotechnol. 2016, 3, 125-130. [CrossRef]

46. Salafzoon, S.; Mahmoodzadeh Hosseini, H.; Halabian, R. Evaluation of the antioxidant impact of ginger-based kombucha on the murine breast cancer model. J. Complement. Integr. Med. 2018, 15, 1-8. [CrossRef] [PubMed]

47. Ayed, L.; Hamdi, M. Manufacture of a beverage from cactus pear juice using "tea fungus" fermentation. Ann. Microbiol. 2015, 65, 2293-2299. [CrossRef]

48. Ayed, L.; Abid, S.B.; Hamdi, M. Development of a beverage from red grape juice fermented with the kombucha consortium. Ann. Microbiol. 2017, 67, 111-121. [CrossRef]

49. Aspiyanto, A.S.; Iskandar, J.M.; Melanie, H.; Maryati, Y.; Lotulung, P.D. Characteristic of fermented spinach (Amaranthus spp.) polyphenol by kombucha culture for antioxidant compound. AIP Conf. Proc. 2017, 1803, 20018. 
50. Yavari, N.; Mazaheri-Assadi, M.; Mazhari, Z.H.; Moghadam, M.B.; Larijani, K. Glucuronic acid rich kombucha-fermented pomegranate juice. J. Food Res. 2017, 7, 61. [CrossRef]

51. Yavari, N.; Assadi, M.M.; Larijani, K.; Moghadam, M.B. Response surface methodology for optimization of glucuronic acid production using kombucha layer on sour cherry juice. Aust. J. Basic Appl. Sci. 2010, 4, 3250-3256.

52. Yavari, N.; Assadi, M.M.; Moghadam, M.B.; Larijani, K.; Researchers, Y. Optimizing glucuronic acid production using tea fungus on grape juice by response surface methodology. Aust. J. Basic Appl. Sci. 2011, 5, 1788-1794.

53. Zofia, N.-L.; Aleksandra, Z.; Tomasz, B.; Martyna, Z.; Tomasz, W. Effect of fermentation time on antioxidant and anti-ageing properties of green coffee. Molecules 2020, 25, 5394. [CrossRef] [PubMed]

54. Tu, C.; Tang, S.; Azi, F.; Hu, W.; Dong, M. Use of kombucha consortium to transform soy whey into a novel functional beverage. J. Funct. Foods 2019, 52, 81-89. [CrossRef]

55. Loňcar, E.; Djurić, M.; Malbaša, R.; Kolarov, L.; Klašnja, A. Influence of working conditions upon kombucha conducted fermentation of black tea. Food Bioprod. Process. 2006, 84, 186-192. [CrossRef]

56. Lončar, E.S.; Kanurić, K.; Malbaša, R.; Đjuric, M.; Milanović, S.D. Kinetics of saccharose fermentation by kombucha. Chem. Ind. Chem. Eng. Q. 2014, 20, 345-352. [CrossRef]

57. Vitas, J.S.; Malbaša, R.V.; Grahovac, J.A.; Lončar, E.S. The antioxidant activity of kombucha fermented milk products with stinging nettle and winter savory. Chem. Ind. Chem. Eng. Q. 2013, 19, 129-139. [CrossRef]

58. Neffe-Skocińska, K.; Sionek, B.; Ścibisz, I.; Kołożyn-Krajewska, D. Acid contents and the effect of fermentation condition of kombucha tea beverages on physicochemical, microbiological and sensory properties. CyTA-J. Food 2017, 15, 601-607. [CrossRef]

59. De Filippis, F.; Dario, A.; Vitaglione, P.; Ercolini, D. Different temperatures select distinctive acetic acid bacteria species and promotes organic acids production during kombucha tea fermentation. Food Microbiol. 2018, 73, 11-16. [CrossRef] [PubMed]

60. Hur, J.; Lee, S.; Kim, Y.-C.; Choi, I.; Kim, G.-B. Effect of fermentation on the antioxidant activity in plant-based foods. Food Chem. 2014, 160, 346-356. [CrossRef] [PubMed]

61. Cvetković, D.D.; Markov, S.L. Preparation of kombucha from winter savory (Satureja montana L.) in the laboratory bioreactor. Acta Period. Technol. 2005, 266, 187-196. [CrossRef]

62. Malbaša, R.; Lončar, E.S.; Vitas, J.; Čanadanovi-Brunet, J.M. Influence of starter cultures on the antioxidant activity of kombucha beverage. Food Chem. 2011, 127, 1727-1731. [CrossRef]

63. Teoh, A.; Heard, G.; Cox, J. Yeast ecology of kombucha fermentation. Int. J. Food Microbiol. 2004, 95, 119-126. [CrossRef] [PubMed]

64. Zhang, W.; Wang, X.; Qi, X.; Ren, L. Isolation and identification of a bacterial cellulose synthesizing strain from kombucha in different conditions: Gluconacetobacter xylinus ZHCJ618. Food Sci. Biotechnol. 2018, 27, 803-811. [CrossRef] [PubMed]

65. Nguyen, V.T.; Flanagan, B.; Gidley, M.J.; Dykes, G.A. Characterization of cellulose production by a Gluconacetobacter xylinus strain from kombucha. Curr. Microbiol. 2008, 57, 449-453. [CrossRef]

66. Mikkelsen, D.; Flanagan, B.M.; Dykes, G.A.; Gidley, M.J. Influence of different carbon sources on bacterial cellulose production by Gluconacetobacter xylinus strain ATCC 53524. J. Appl. Microbiol. 2009, 107, 576-583. [CrossRef] [PubMed]

67. Coton, M.; Pawtowski, A.; Taminiau, B.; Burgaud, G.; Deniel, F.; Coulloumme-Labarthe, L.; Fall, A.; Daube, G.; Coton, E. Unraveling microbial ecology of industrial-scale kombucha fermentations by metabarcoding and culture-based methods. FEMS Microbiol. Ecol. 2017, 93, fix048. [CrossRef]

68. Zhang, H.; Zhang, Z.; Xin, X. Isolation and identification of microorganisms from kombucha fungus culture. J. Beijing Union Univ. 2011, 25, 42-46.

69. Wu, W.; Gai, B.-C.; Ji, B.-P. Study on the isolation and identification of microbes of kombucha. J. Food Sci. 2004, $25,55-58$.

70. Arikan, M.; Mitchell, A.; Finn, R.; Gurel, F. Microbial composition of kombucha determined using amplicon sequencing and shotgun metagenomics. J. Food Sci. 2020, 85, 455-464. [CrossRef] [PubMed]

71. Harrison, K.; Curtin, C. Microbial composition of SCOBY starter cultures used by commercial kombucha brewers in North America. Microorganisms 2021, 9, 1060. [CrossRef] [PubMed]

72. Fu, C.; Yan, F.; Cao, Z.; Xie, F.; Lin, J. Antioxidant activities of kombucha prepared from three different substrates and changes in content of probiotics during storage. Food Sci. Technol. 2014, 34, 123-126. [CrossRef]

73. Mukadam, T.A.; Punjabi, K.; Deshpande, S.D. Isolation and characterization of bacteria and yeast from kombucha tea. Int. J. Curr. Microbiol. Appl. Sci. 2016, 5, 32-41. [CrossRef]

74. Watawana, M.I.; Jayawardena, N.; Ranasinghe, S.J.; Waisundara, V.Y. Evaluation of the effect of different sweetening agents on the polyphenol contents and antioxidant and starch hydrolase inhibitory properties of kombucha. J. Food Process. Preserv. 2017, 41, e12752. [CrossRef]

75. Angela, C.; Young, J.; Kordayanti, S.; Devanthi, P.V.P.; Katherine. Isolation and screening of microbial isolates from kombucha culture for bacterial cellulose production in sugarcane molasses medium. In Proceedings of the 2019 International Conference on Biotechnology and Life Sciences, Kolkata, India, 8-10 August 2019; CRC Press: Boca Raton, FL, USA, 2020; Volume 2020, pp. 111-127.

76. Villarreal-Soto, S.A.; Bouajila, J.; Pace, M.; Leech, J.; Cotter, P.D.; Souchard, J.; Taillandier, P.; Beaufort, S. Metabolome-microbiome signatures in the fermented beverage, kombucha. Int. J. Food Microbiol. 2020, 333, 108778. [CrossRef]

77. Wang, S.; Zhang, L.; Qi, L.; Liang, H.; Lin, X.; Li, S.; Yu, C.; Ji, C. Effect of synthetic microbial community on nutraceutical and sensory qualities of kombucha. Int. J. Food Sci. Technol. 2020, 55, 3327-3333. [CrossRef] 
78. Leonarski, E.; Cesca, K.; Borges, O.M.A.; de Oliveira, D.; Poletto, P. Typical kombucha fermentation: Kinetic evaluation of beverage and morphological characterization of bacterial cellulose. J. Food Process. Preserv. 2021, 45, e16100. [CrossRef]

79. Savary, O.; Mounier, J.; Thierry, A.; Poirier, E.; Jourdren, J.; Maillard, M.; Penland, M.; Decamps, C.; Coton, E.; Coton, M. Tailor-made microbial consortium for kombucha fermentation: Microbiota-induced biochemical changes and biofilm formation. Food Res. Int. 2021, 147, 110549. [CrossRef]

80. Tran, T.; Grandvalet, C.; Winckler, P.; Verdier, F.; Martin, A.; Alexandre, H.; Tourdot-Maréchal, R. Shedding light on the formation and structure of kombucha biofilm using two-photon fluorescence microscopy. Front. Microbiol. 2021, 12, 1-13. [CrossRef]

81. Ma, C.; Lin, J.; Yang, M.; Liu, Z. Optimization of technical conditions in the fermentation of kombucha. Food Res. Dev. 2008, 29, 36-38.

82. Edwards, C.G.; Collins, M.D.; Lawson, P.A.; Rodriguez, A.V. Lactobacillus nagelii sp. nov., an organism isolated from a partially fermented wine. Int. J. Syst. Evol. Microbiol. 2000, 50, 699-702. [CrossRef] [PubMed]

83. Furukawa, S.; Yoshida, K.; Ogihara, H.; Yamasaki, M.; Morinaga, Y. Mixed-species biofilm formation by direct cell-cell contact between brewing yeasts and lactic acid bacteria. Biosci. Biotechnol. Biochem. 2010, 74, 2316-2319. [CrossRef] [PubMed]

84. May, A.; Narayanan, S.; Alcock, J.; Varsani, A.; Maley, C.; Aktipis, A. Kombucha: A novel model system for cooperation and conflict in a complex multi-species microbial ecosystem. PeerJ 2019, 2019, 1-22. [CrossRef] [PubMed]

85. Bergström, H. The Effect of the Fermented Tea Beverage Kombucha on the Gut Microflora. Master's Thesis, Lund University, Lund, Sweden, 2018.

86. U.S. National Library of Medicine. The Effect of the Fermented Tea Beverage Kombucha on the Oral and Gut Microflora (NCT03873350). Available online: https:/ / clinicaltrials.gov/ct2/show / NCT03873350?term=Kombucha\&draw=2\&rank=1 (accessed on 8 December 2021).

87. U.S. National Library of Medicine. Evaluating the Effects of Kombucha as a Hyperglycaemic Therapeutic Agent within Diabetic Human Subjects (NCT04107207). Available online: https:/ clinicaltrials.gov/ct2/show / NCT04107207?term=Kombucha\&draw= 2\&rank=2 (accessed on 8 December 2021).

88. U.S. National Library of Medicine. The Effect of Kombucha on Blood Sugar Levels in Humans (NCT04051294). Available online: https: / / clinicaltrials.gov/ ct2/ show / NCT04051294?term=Kombucha\&draw=2\&rank=3 (accessed on 8 December 2021).

89. Shahbazi, H.; Hashemi Gahruie, H.; Golmakani, M.T.; Eskandari, M.H.; Movahedi, M. Effect of medicinal plant type and concentration on physicochemical, antioxidant, antimicrobial, and sensorial properties of kombucha. Food Sci. Nutr. 2018, 6, 2568-2577. [CrossRef] [PubMed]

90. Sknepnek, A.; Pantić, M.; Matijašević, D.; Miletić, D.; Lević, S. Novel kombucha beverage from Lingzhi or Reishi medicinal mushroom Ganoderma lucidum with antibacterial and antioxidant affects. Int. J. Med. Mushrooms 2018, 20, 243-258. [CrossRef] [PubMed]

91. Tan, W.C.; Muhialdin, B.J.; Meor Hussin, A.S. Influence of storage conditions on the quality, metabolites, and biological activity of Soursop (Annona muricata. L.) kombucha. Front. Microbiol. 2020, 11, 2982. [CrossRef] [PubMed]

92. Zubaidah, E.; Dewantari, F.J.; Novitasari, F.R.; Srianta, I.; Blanc, P.J. Potential of snake fruit (Salacca zalacca (Gaerth.) Voss) for the development of a beverage through fermentation with the kombucha consortium. Biocatal. Agric. Biotechnol. 2018, 13, 198-203. [CrossRef]

93. Al-Mohammadi, A.R.; Ismaiel, A.A.; Ibrahim, R.A.; Moustafa, A.H.; Zeid, A.A.; Enan, G. Chemical constitution and antimicrobial activity of kombucha fermented beverage. Molecules 2021, 26, 5026. [CrossRef] [PubMed]

94. Ivanisova, E.; Menhartova, K.; Terentjeva, M.; Harangozo, L.; Kantor, A.; Kacaniova, M. The evaluation of chemical, antioxidant, antimicrobial and sensory properties of kombucha tea beverage. J. Food Sci. Technol. 2020, 57, 1840-1846. [CrossRef]

95. Nazemi, L.; Hashemi, S.J.; Ghazvini, R.D.; Saeedi, M.; Khodavaisy, S.; Barac, A.; Modiri, M.; Dana, M.A.; Shahrabadi, Z.Z.; Rezaie, S. Investigation of cgrA and cyp51A gene alternations in Aspergillus fumigatus strains exposed to kombucha fermented tea. Curr. Med. Mycol. 2019, 5, 36-42. [CrossRef]

96. Fu, N.; Wu, J.; Lv, L.; He, J.; Jiang, S. Anti-foot-and-mouth disease virus effects of Chinese herbal kombucha in vivo. Braz. J. Microbiol. 2015, 46, 1245-1255. [CrossRef] [PubMed]

97. Cobbina, E.; Akhlaghi, F. Non-alcoholic fatty liver disease (NAFLD)—Pathogenesis, classification, and effect on drug metabolizing enzymes and transporters. Drug Metab. Rev. 2018, 49, 197-211. [CrossRef]

98. Cardoso, R.; Moreira, L.P.; de Campos Costa, M.; Toledo, R.C.; Grancieri, M.; Nascimento, T.P.; Ferreira, M.S.; da Matta, S.L.; Eller, M.R.; Duarte Martine, H.; et al. Kombucha from green and black teas reduce oxidative stress, liver steatosis and inflammation, and improve glucose metabolism in Wistar rats fed a high-fat high-fructose diet. Food Funct. 2021, 12, 10813-10827. [CrossRef]

99. Lee, C.; Kim, J.; Wang, S.; Sung, S.; Kim, N.; Lee, H.; Seo, Y.; Jung, Y. Hepatoprotective effect of kombucha tea in rodent model of nonalcoholic fatty liver disease/nonalcoholic steatohepatitis. Int. J. Mol. Sci. 2019, 20, 2369. [CrossRef]

100. Urrutia, M.A.; Ramos, A.; Menegusso, R.B.; Lenz, R.; Ramos, M.; Tarone, A.; Cazarin, C.B.; Cottica, S.; da Silva, S.A.; Bernardi, D. Effects of supplementation with kombucha and green banana flour on Wistar rats fed with a cafeteria diet. Heliyon 2021, 7, e07081. [CrossRef]

101. Zubaidah, E.; Apriyadi, T.E.; Kalsum, U.; Widyastuti, E.; Estiasih, T.; Srianta, I.; Blanc, P.J. In vivo evaluation of snake fruit kombucha as hyperglycemia therapeutic agent. Int. Food Res. J. 2018, 25, 453-457.

102. Zubaidah, E.; Afgani, C.A.; Kalsum, U.; Srianta, I.; Blanc, P.J. Comparison of in vivo antidiabetes activity of snake fruit kombucha, black tea kombucha and metformin. Biocatal. Agric. Biotechnol. 2019, 17, 465-469. [CrossRef] 
103. Constantinescu, C.S.; Farooqi, N.; Brien, K.O.; Gran, B. Experimental autoimmune encephalomyelitis (EAE) as a model for multiple sclerosis (MS). Br. J. Pharmacol. 2011, 164, 1079-1106. [CrossRef]

104. Haghmorad, D.; Yazdanpanah, E.; Sadighimoghaddam, B.; Yousefi, B.; Sahafi, P. Kombucha ameliorates experimental autoimmune encephalomyelitis through activation of Treg and Th2 cells. Acta Neurol. Belg. 2021, 121, 1685-1692. [CrossRef]

105. Sknepnek, A.; Tomić, S.; Miletić, D.; Lević, S.; Čolić, M. Kombucha beverages and immunomodulatory potential of their polysaccharide extracts. Food Chem. 2021, 342, 128344. [CrossRef] [PubMed]

106. Kovacevic, Z.; Davidovic, G.; Vuckovic-Filipovic, J.; Janicijevic-Petrovic, M.A.; Janicijevic, K.; Popovic, A. A toxic hepatitis caused the kombucha tea-Case report. Open Access Maced. J. Med. Sci. 2014, 2, 128-131. [CrossRef]

107. Derk, C.T.; Sandorfi, N.; Curtis, M.T. A case of anti-Jo1 myositis with pleural effusions and pericardial tamponade developing after exposure to a fermented kombucha beverage. Clin. Rheumatol. 2004, 23, 355-357. [CrossRef]

108. Wood, B.; Rademaker, M.; Oakley, A.; Wallace, J. Pellagra in a woman using alternative remedies. Australas. J. Dermatol. 1998, 39, 42-44. [CrossRef]

109. Moreira, P.L.; Lourencao, T.B.; Pinto, J.P.A.N.; Rall, V.L.M. Microbiological quality of spices marketed in the city of Botucatu, Sao Paulo, Brazil. J. Food Prot. 2009, 72, 421-424. [CrossRef]

110. Sagoo, S.K.; Little, C.L.; Greenwood, M.; Mithani, V.; Grant, K.A.; McLauchlin, J.; de Pinna, E.; Threlfall, E.J. Assessment of the microbiological safety of dried spices and herbs from production and retail premises in the United Kingdom. Food Microbiol. 2009, 26, 39-43. [CrossRef] [PubMed]

111. Sospedra, I.; Soriano, J.M.; Mañes, J. Assessment of the microbiological safety of dried spices and herbs commercialized in Spain. Plant Foods Hum. Nutr. 2010, 65, 364-368. [CrossRef]

112. Ossowski, M.; Nowakowicz-Dębek, B.; Wlazło, L.; Król, J.; Kasela, M.; Maksym, P.; Malm, A. Evaluation of microbiological contamination of black and green teas. Adv. J. Food Sci. Technol. 2019, 17, 65-71. [CrossRef]

113. Carraturo, F.; De Castro, O.; Troisi, J.; De Luca, A.; Masucci, A.; Cennamo, P.; Trifuoggi, M.; Aliberti, F.; Guida, M. Comparative assessment of the quality of commercial black and green tea using microbiology analyses. BMC Microbiol. 2018, 18, 1-12. [CrossRef] [PubMed]

114. Centers for Disease Control and Prevention. Unexplained severe illness possibly associated with consumption of kombucha tea-Iowa, 1995. Morb. Mortal. Wkly. Rep. 1995, 44, 892-893.

115. Sadjadi, J. Cutaneous anthrax associated with the kombucha "mushroom" in Iran. J. Am. Med. Assoc. 1998, 280, 1567-1568. [CrossRef]

116. Brewer, S.S.; Lowe, C.A.; Beuchat, L.R.; Ortega, Y.R. Survival of Salmonella and Shiga toxin-producing Escherichia coli and changes in indigenous microbiota during fermentation of home-brewed kombucha. J. Food Prot. 2021, 84, 1366-1373.

117. Nummer, B.A. Kombucha brewing under the Food and Drug Administration model Food Code: Risk analysis and processing guidance. J. Environ. Health 2013, 76, 8-11.

118. Sundermann, A.; Zhao, S.; Young, C.; Lam, L.; Jones, S. Alcohol use in pregnancy and miscarriage: A systematic review and meta-analysis. Alcohol. Clin. Exp. Res. 2019, 43, 1606-1616. [CrossRef]

119. Hon, K.L.; Leung, A.K.C.; Cheung, E.; Lee, B.; Tsang, M.M.C.; Torres, A.R. An overview of exposure to ethanol-containing substances and ethanol intoxication in children based on three illustrated cases. Drugs Context 2018, 7, 5-9. [CrossRef] [PubMed]

120. Phan, T.G.; Estell, J.; Duggin, G.; Beer, I.; Smith, D.; Ferson, M.J. Lead poisoning from drinking kombucha tea brewed in a ceramic pot. Med. J. Aust. 1998, 169, 644-646. [CrossRef]

121. PepsiCo. PepsiCo Announces Definitive Agreement to Acquire KeVita, a Leader in Fermented Probiotic Beverages. Available online: https:/ / www.pepsico.com/news / press-release/pepsico-announces-definitive-agreement-to-acquire-kevita-a-leaderin-fermented-p11222016 (accessed on 1 December 2021).

122. Frost, P. Molson Coors acquires Clearly Kombucha. Available online: https://www.molsoncoorsblog.com/news/molson-coorsacquires-clearly-kombucha (accessed on 1 December 2021).

123. Coca-Cola. The Coca-Cola Company Adds Its First Line of Kombucha through Acquisition of Australian-Based Organic \& Raw Trading Co. Available online: https:/ / www.coca-colacompany.com/au/media-centre/media-releases/coca-cola-companyadds-kombucha-acquisition-australian-organic-raw-trading-co (accessed on 1 December 2021).

124. Caballero, M. Health-Ade Lands \$20M Coke Equity Investment. Available online: https://www.bevnet.com/news/2019/reportcoke-veb-reups-in-health-ade/ (accessed on 1 December 2021).

125. Peel, A.G. First Bev Buys Controlling Stake in Kombucha Brand Health-Ade. Available online: https://www.foodbev.com/news / first-bev-buys-controlling-stake-in-kombucha-brand-health-ade/ (accessed on 1 December 2019).

126. Caballero, M. Peet's Acquire Majority Stake in Revive Kombucha. Available online: https://www.bevnet.com/news/2018/peetsacquires-majority-stake-in-revive-kombucha/ (accessed on 1 December 2021).

127. World Health Organisation. Global Status Report on Alcohol and Health 2018; World Health Organisation: Geneva, Switzerland, 2018.

128. Treatt. Supplier of Flavour, Fragrance Ingredients. Available online: https:/ / www.treatt.com/ (accessed on 1 December 2021).

129. International Food Information Council. 2021 Food \& Health Survey; International Food Information Council: Washington, DC, USA, 2021.

130. Mellentin, J. 10 Key Trends in Food, Nutrition \& Health 2022; New Nutrition Business: London, UK, 2022.

131. Maathuis, A.J.H.; Keller, D.; Farmer, S. Survival and metabolic activity of the GanedenBC30 strain of Bacillus coagulans in a dynamic in vitro model of the stomach and small intestine. Benef. Microbes 2010, 1, 31-36. [CrossRef] [PubMed] 
132. Majeed, M.; Nagabhushanam, K.; Natarajan, S.; Sivakumar, A.; Eshuis-de Ruiter, T.; Booij-Veurink, J.; de Vries, Y.P.; Ali, F. Evaluation of genetic and phenotypic consistency of Bacillus coagulans MTCC 5856: A commercial probiotic strain. World J. Microbiol. Biotechnol. 2016, 32, 1-12. [CrossRef] [PubMed]

133. Lavrentev, F.V.; Ashikhmina, M.S.; Ulasevich, S.A.; Morozova, O.V.; Orlova, O.Y.; Skorb, E.V.; Iakovchenko, N.V. Perspectives of Bacillus coagulans MTCC 5856 in the production of fermented dairy products. LWT 2021, 148, 111623. [CrossRef]

134. Majeed, M.; Majeed, S.; Nagabhushanam, K.; Arumugam, S.; Beede, K.; Ali, F. Evaluation of probiotic Bacillus coagulans MTCC 5856 viability after tea and coffee brewing and its growth in GIT hostile environment. Food Res. Int. 2019, 121, 497-505. [CrossRef]

135. Jang, S.S.; McIntyre, L.; Chan, M.; Brown, P.; Finley, J.; Chen, S.X. Ethanol concentration of kombucha teas in British Columbia, Canada. J. Food Prot. 2021, 84, 1878-1883. [CrossRef]

136. Food Safety Authority of Ireland Food Safety Guidance Published for Unpasteurised Fermented Plant-Based Products. Available online: https://www.fsai.ie/news_centre/press_releases/fermented_products_guidance_23092021.html (accessed on 2 December 2021).

137. Food Standards Australia New Zealand Food Recall-Lychee Rose Kombucha 330 mL. Available online: https://www. foodstandards.gov.au/industry/foodrecalls/recalls/Pages/Lychee-Rose-Kombucha-330ml-.aspx (accessed on 2 December 2021).

138. LeBlanc, C.S. The Kombucha Tea Recall. Available online: https://www.law.uh.edu/healthlaw/perspectives/2010/leblanc_ kombucha.pdf (accessed on 2 December 2021).

139. Kombucha Brewers International. The Kombucha Act (H.R. 2124/S. 892) Is Changing Our Industry. Available online: https: / / kombuchabrewers.org/lobbying/ (accessed on 2 December 2021). 